\title{
Dynamics of Single Potassium Channel Proteins in the Plasma Membrane of Migrating Cells
}

\author{
Dissertation \\ zur Erlangung des akademischen Grades \\ doctor rerum naturalium \\ (Dr.rer.nat.)
}

vorgelegt dem Rat der Biologisch-Pharmazeutischen Fakultät der Friedrich-Schiller-Universität Jena

Von

(Master of Science) Volodymyr Nechyporuk-Zloy Geboren am 18.10.1976

in Chernivci, Ukraine 


\section{Gutachter:}

1 Prof. Dr. Otto Karl Greulich (Leibniz Institut für Altersforschung - Fritz-LipmannInstitut, Jena)

2 Prof. Dr. Stefan H Heinemann (Friedrich-Schiller-Universität, Jena)

3 Prof. Dr. Walter Stühmer (Max-Plack-Institut für Experimentelle Medizin)

Tag der Doktorprüfung $\quad 21.06 .2007$

Tag der öffentlichen Verteidigung $\quad 24.07 .2007$ 


\section{TABLE OF CONTENTS}

SUMMARY II

ZUSAMMENFASSUNG IV

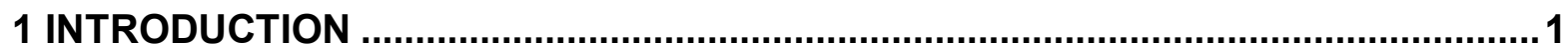

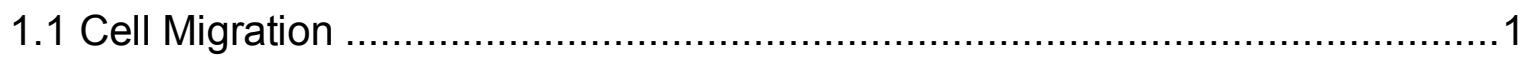

1.2 Role of Ion Channels in Cell Migration ..................................................... 4

1.3 Distribution and Recycling of $\mathrm{K}_{\mathrm{Ca}} 3.1$ Channel Proteins in Migrating Cells ........5

1.4 Single Molecule Approach ........................................................................

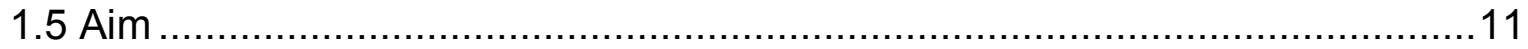

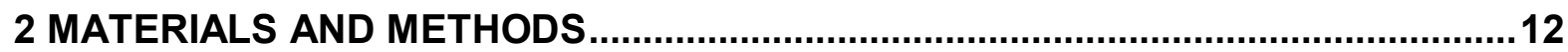

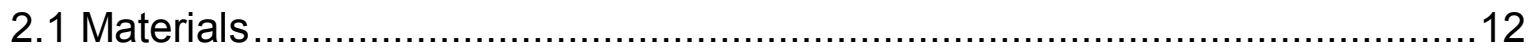

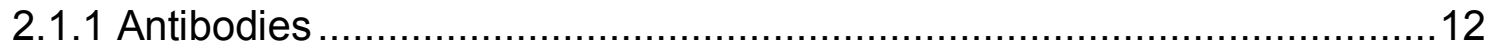

2.1.2 Quantum Dot Conjugates .............................................................. 12

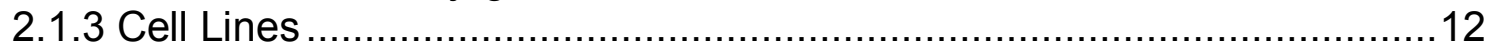

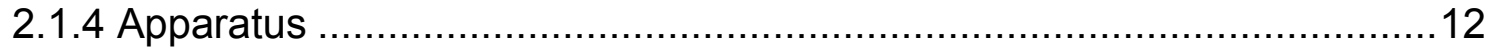

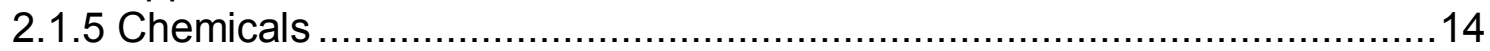

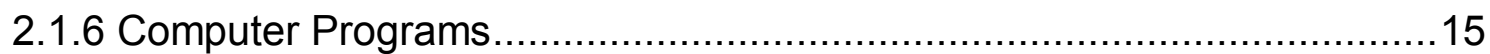

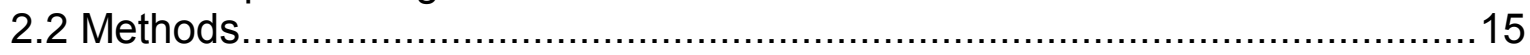

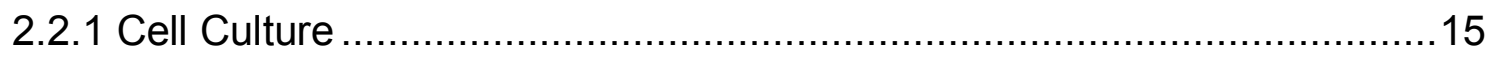

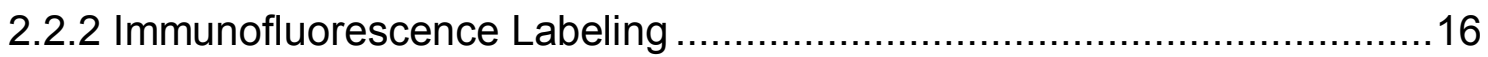

2.2.3 Microscopy and Data Acquisition ................................................. 17

2.2.4 Analysis of Cell Migration................................................................

2.2.5 Tracking of $\mathrm{K}_{\mathrm{Ca}} 3.1$ Channels.........................................................

2.2.6 Analysis of $\mathrm{K}_{\mathrm{Ca}} 3.1$ Dynamics ..........................................................

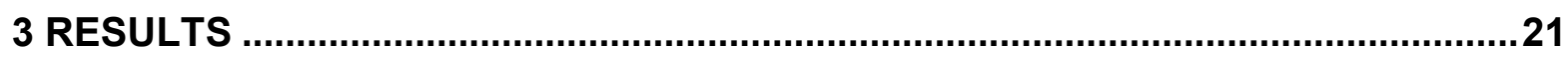

3.1 Detection of Single Potassium Channel Proteins ................................... 21

3.2 Dynamics of Single Potassium Channel Proteins..................................... 25

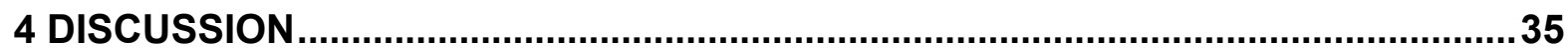

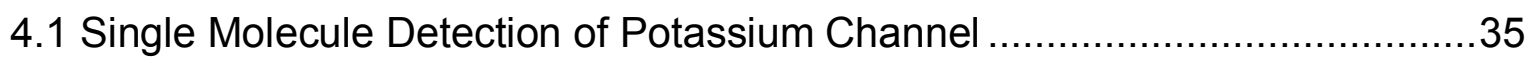

4.2 Motion of $\mathrm{K}_{\mathrm{Ca}} 3.1$ Channel Protein in the Plasma Membrane is Subdiffusive ..37

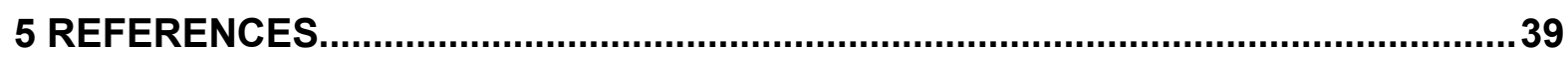

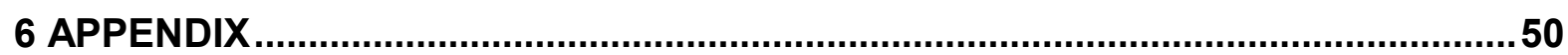

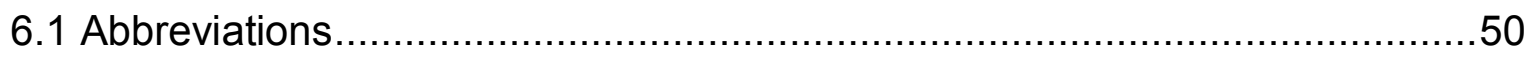

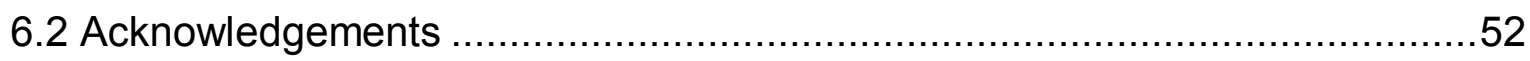

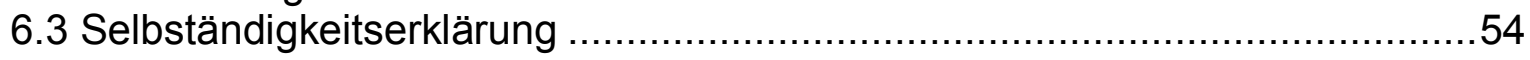

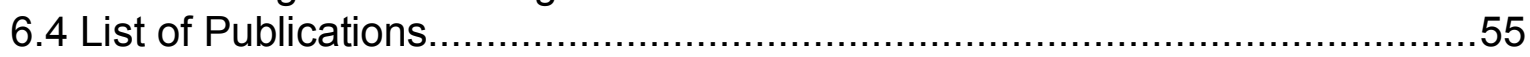

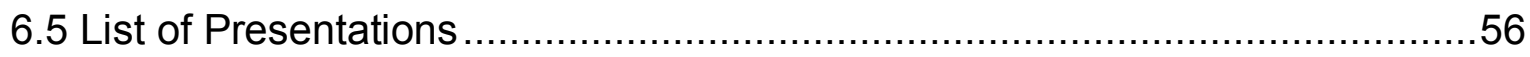

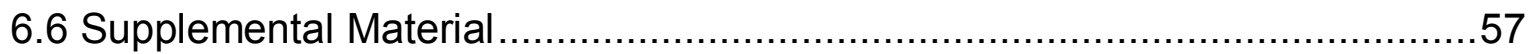

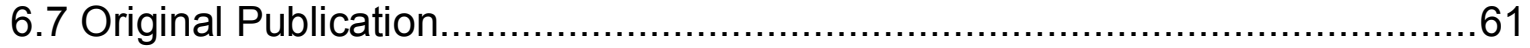




\section{Summary}

Cell migration is an important cell physiological process, which among others is controlled by regulated ion channel activity. It has been revealed that potassium channels, in particular calcium-activated potassium channels $\left(\mathrm{K}_{\mathrm{Ca}} 3.1\right)$, are required for optimal cell migration (Schwab et al., 2007). In the plasma membrane, $\mathrm{K}_{\mathrm{Ca}} 3.1$ channel proteins are preferentially concentrated near the leading edge of the migrating cells. Such subcellular distribution could be the direct result of an endocytic recycling of $\mathrm{K}_{\mathrm{Ca}} 3.1$ channels or the linkage between the channel proteins and the cytoskeleton at the cell pole. In the latter the $\mathrm{K}_{\mathrm{Ca}} 3.1$ channel should be immobile and could form clusters.

In order to study the dynamics of individual channel proteins in the plasma membrane, single channel proteins were identified and tracked during cell migration. The identification was based on dual-colour labeling with quantum dots (QD) and it was proven that more than $90 \%$ of the observed QDs correspond to single potassium channel proteins (Nechyporuk-Zloy et al., 2006). No clusters of $\mathrm{K}_{\mathrm{Ca}} 3.1$ channels were observed in the plasma membrane. In migrating MDCK-F cells $\left(N_{\text {cells }}\right.$ $=10)$ single $Q D$-labeled channels $\left(N_{Q D}=534\right)$ were visualised and tracked using time lapse total internal reflection fluorescence (TIRF) microscopy. The primary motion was subdiffusion with mean diffusion coefficient $D_{\alpha}=0.067 \pm 0.0005 \mu \mathrm{m}^{2} / \mathrm{s}$ and subdiffusion exponent $\alpha=0.82 \pm 0.003$. The ion channel proteins had smaller subdiffusion exponents at the lamellipodium and at the uropod than in the body of the cell. Finally, the calculation of the kurtosis of the mobile $\mathrm{K}_{\mathrm{Ca}} 3.1$ channels as function of time demonstrates a saturation at a value of slightly above 4 . This showed a high probability for the channel protein to be near the starting point or far away in comparison to normal diffusion during observation.

The data indicate that subdiffusion is the main dynamical process for the transport of the $\mathrm{K}_{\mathrm{Ca}} 3.1$ channels in the membrane (Nechyporuk-Zloy et al., 2007). Moreover, the direct binding of the channel proteins to the cytoskeleton proteins at this cell pole does not cause the concentration of $\mathrm{K}_{\mathrm{Ca}} 3.1$ channels at the leading edge of migrating cells. The subdiffusive motion of $\mathrm{K}_{\mathrm{Ca}} 3.1$ channels in the plasma membrane means more slow diffusion compared to free diffusion which may be caused by 
obstacles in the plasma membrane. For example, the interaction of the ion channel proteins with the membrane cytoskeleton or their association with the lipid rafts. Taken together, the results point at the complexity of the ion channel protein motion in the plasma membrane.

My method for the single ion channel identification provides an easy way to detect a single ion channel protein in the plasma membrane by using a conventional epifluorescence microscopy. The procedure for verification of single molecule detection is sufficiently simplified and provide, an ordinary physiological lab a routine single molecule ion channel detection technique. Prior success has resulted in the adoption to the labelling technique of amiloride-sensitive epithelial sodium channels (ENaC) (Kusche et al., 2007). 


\section{Zusammenfassung}

Die Zellwanderung stellt einen wichtigen zellphysiologischen Prozess dar, der unter anderem durch die Aktivität von Ionenkanälen reguliert wird. Es konnte nachgewiesen werden, dass Kaliumkanäle, insbesondere die $\mathrm{Ca}^{2+}$-aktivierten Kaliumkanäle ( $\left.\mathrm{K}_{\mathrm{Ca}} 3.1\right)$, für eine optimale Zellwanderung erforderlich sind (Schwab et al., 2007). In der Plasmamembran wandernder Zellen konzentrieren sich $\mathrm{K}_{\mathrm{Ca}}$ 3.1Kanalproteine bevorzugt in der Nähe des Leitsaums. Diese subzelluläre Verteilung könnte das direkte Ergebnis einer endozytotischen Wiederverwertung (endocytic

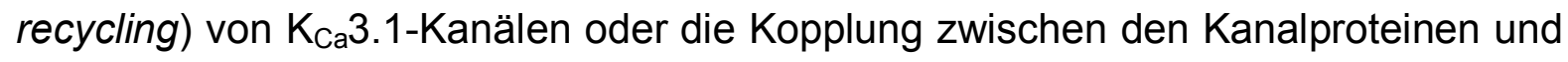
den Zytoskelett-Komponenten an diesem Zellpol darstellen. Im letzteren Fall sollten

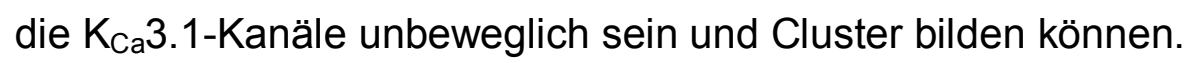

Um die Dynamik einzelner Kanalproteine der Plasmamembrane zu studieren, wurden zunächst einzelne Kanalproteine identifiziert und ihr Verhalten während der Zellwanderung verfolgt. Mittels Nachweis einzelner Kanalproteine - basierend auf der Zweifarbmarkierung (dual-colour labeling) mithilfe so genannter Quantum Dots (QDs) - wurde belegt, dass mehr als $90 \%$ der beobachteten QDs einzelne $\mathrm{K}^{+}$Kanalproteine darstellen (Nechyporuk-Zloy et al., 2006). In der Plasmamembran wurden keine $\mathrm{K}_{\mathrm{ca}} 3.1-\mathrm{Kanalprotein}-\mathrm{Cluster}$ nachgewiesen. Unter Verwendung der Zeitraffer-Total-Internal-Reflektion-Fluorescence-Mikroskopie (times lapse TIRF microscopy) wurden einzelne QD-markierte Kanäle $\left(N_{Q D}=534\right)$ in wandernden MDCK-F-Zellen $\left(\mathrm{N}_{\text {Zellen }}=10\right.$ ) sichtbar gemacht und deren Bewegung verfolgt. Den Hauptbewegungstyp stellte die Subdiffusion mit einem mittleren Diffusionskoeffizienten von $D_{\alpha}=0.067 \pm 0.0005 \mu \mathrm{m}^{2} / \mathrm{s}^{\alpha}$ und einem Subdiffusionsexponenten $\alpha=0.82 \pm 0.003$. Die lonenkanalproteine wiesen am Lamellipodium und Uropodium einen niedrigeren Subdiffusionexponenten als am Zellkörper auf. Die Kalkulation der Kurtosis von beweglichen $\mathrm{K}_{\mathrm{Ca}} 3.1$-Kanäle als Funktion der Zeit ergab eine Sättigung bei einem Wert von etwas über 4. Dieses Ergebnis lässt vermuten, dass das Kanalprotein - im Vergleich zur normalen Diffusion während der Beobachtung - sich mit hoher Wahrscheinlichkeit in der Nähe oder weit weg des Ausgangspunktes befindet. 
Die Daten zeigen, dass Subdiffusion die Hauptkomponente des dynamischen Transportprozesses vom $\mathrm{K}_{\mathrm{Ca}} 3.1-$ Kanälen in der Membrane darstellt. Die direkte Bindung der Kanalproteine an Zellskelett-Proteinkomponenten am Leitsaum wandernder Zellen sich nicht wahrscheinlich ist (Nechyporuk-Zloy et al., 2007). Die subdiffusive Bewegung der $\mathrm{K}_{\mathrm{Ca}} 3$.1-Kanälen in der Plasmamembran entspricht einer eher langsamen Diffusion als einer freien Diffusion und wird möglicherweise durch Behinderungen verursacht: zum Beispiel durch Wechselwirkung der lonenkanalproteine mit den Zellskelett-Komponenten der Plasmamembran oder deren Assoziation mit Lipidgruppen. Die vorgestellten Ergebnisse deuten auf eine komplexe lonenkanal-Proteinbewegung innerhalb der Plasmamembran hin.

Meine Methode zur Identifizierung einzelner lonenkanäle stellt einen mittels konventioneller Epifluoreszenzmikroskopie leicht zugänglichen Weg dar, um einzelne lonenkanalproteine in der Plasmamembrane nachzuweisen. Das vorgestellte Verfahren zur Verifizierung einzelner Moleküle ist einfach genug um in einem gewöhnlichen physiologischen Labor als Routinetechnik zur Darstellung einzelner lonenkanalproteine eingesetzt werden zu können. Die Methode konnte bereits erfolgreich zur Markierung Amilorid-sensitiver epithelialer Natriumkanäle (ENaC) adaptiert werden (Kusche et al., 2007). 


\section{Introduction}

\subsection{Cell Migration}

Cell migration is a significant process that occurs in uni-cellular organisms such as, amoeba, where its main function is the search for food (Vicente-Manzanares et al., 2005; Manahan et al., 2004; van Haastert and Devreotes, 2004), as well as in multicellular organisms, where it is crucial for the embryonic development (Ridley et al., 2003), the inflammatory immune response (Koch et al., 2006), wound repair (Martin and Leibovich, 2005), tumour formation and metastasis (Kopfstein and Christofori, 2006). There are different types of cell migration: swimming by means of flagella, typical for bacteria and mammalian sperm cells; swimming by a coordinated beat of cilia, common in protozoa; creeping, which is typical for amoebae, diatoms, and some types of cyanobacteria; and crawling - the common type of locomotion of cells in a multi-cellular animals, such as white blood cells, cells in the developing embryo, tips of growing nerve axons, and cancer cells (Bray, 2001). The velocity of cell movement ranges from $30 \mu \mathrm{m} / \mathrm{min}$ for fast-moving cells like neutrophils, which seem to glide over their substratum, to $0.8-1 \mu \mathrm{m} / \mathrm{min}$ for slow-moving cells as fibroblasts (Ridley et al., 2003). The details of migration in these types of cells can differ. Here I focus on the slow-moving kind of cell migration.

The typical crawling cell that migrates in response to a migration-promoting agent polarizes and extends protrusions to the direction of migration due to actin polymerisation (Fig. 1.1). These consist protrusions can be found in form of filopodia - fine hairlike extensions about 0.1-0.2 $\mu \mathrm{m}$ in diameter and up to $20 \mu \mathrm{m}$ in length, or lamellipodia (Fig. 1.2) - the sheets or veils of membrane-enclosed cytoplasm of a thickness similar to filopodia (Bray, 2001). The protrusions are stabilised by adhering to the extracellular matrix to adjacent cells mediated by transmembrane receptors linked to the actin cytoskeleton. The cell moves forward, releases the focal contacts at the rear part of the cell, which helps to retract the rear part of the cell (Ridley et al., 2003). This is a cyclic process. What is the driving force for cell protrusions? In lamellipodia actin filaments are organised in form of branches which are produced by Arp2/3 complexes (Borisy and Svitkina, 2000;Svitkina and Borisy, 1999). Actin filaments are constantly bending because of thermal energy (Blanchoin et al., 2000;Mogilner and Oster, 1996;Pollard and Borisy, 2003). 

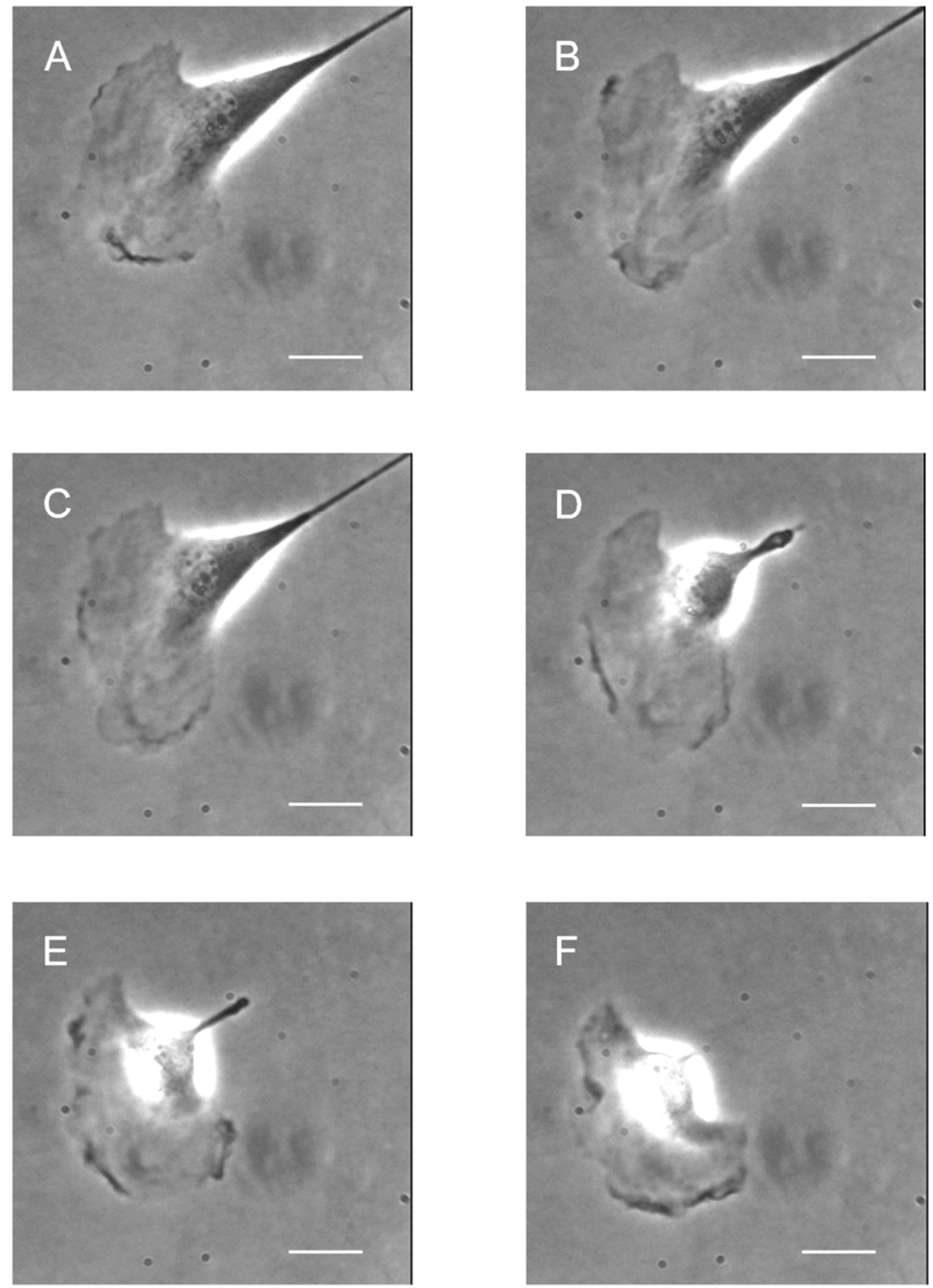

Figure 1.1: Migration of a MDCK-F cell. (A-C), (F) Extension of protrusion. (D-E) Retraction of the rear part. Migratory velocity of the cell is $1 \mu \mathrm{m} / \mathrm{min}$. Bar: $25 \mu \mathrm{m}$. 

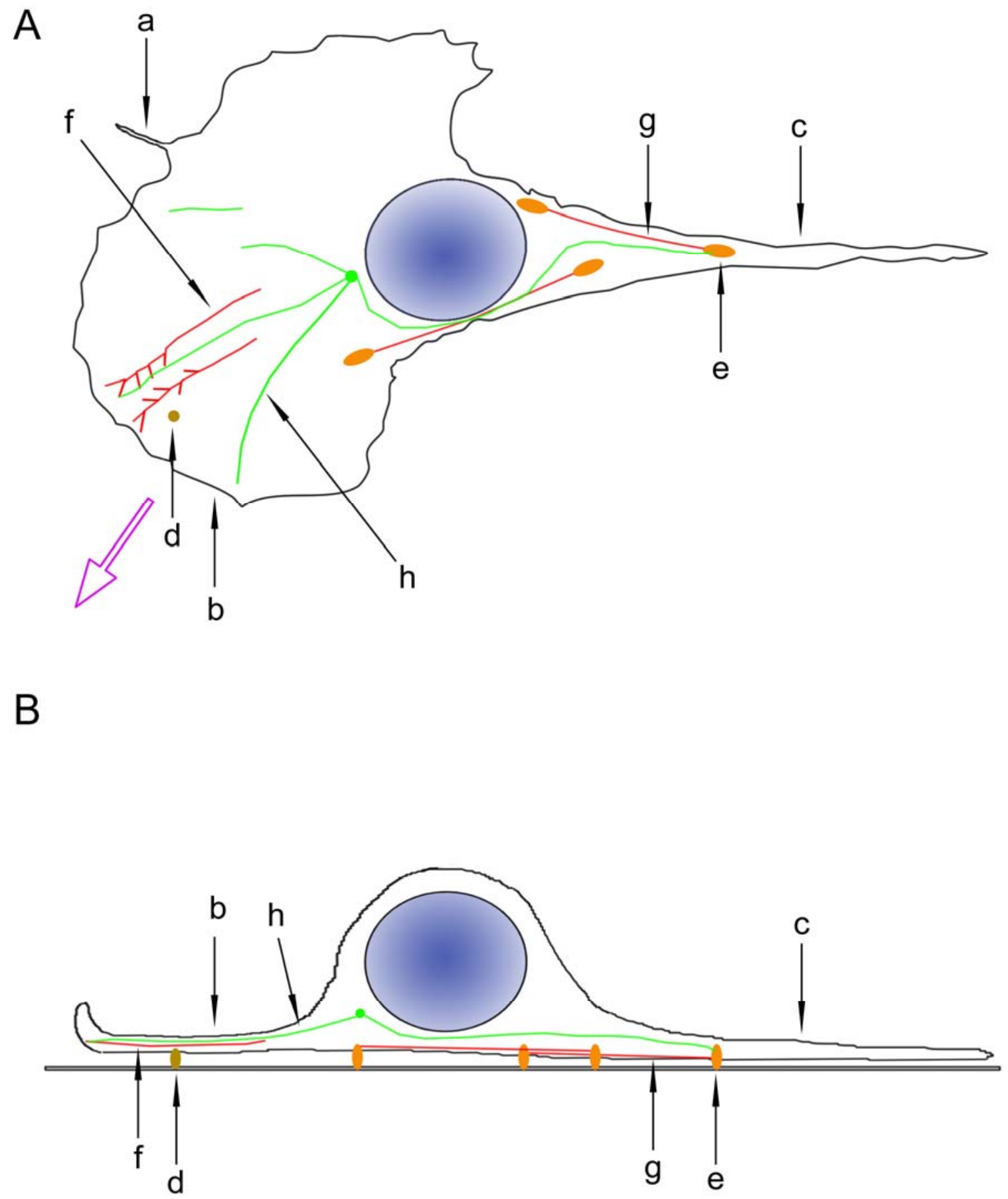

Figure 1.2: A migrating cell. (A) Top view. (B) Side view. a. filopodium, b. lamellipodium, c. rear part (uropod), d. transmembrane receptor, e. focal contact, f. actin filament, g. stress fibre, h. microtubule, purple arrow shows the direction of the cell movement. 
When bent away from the surface of the cytosolic leaflet of the plasma membrane, an actin subunit can be added, lengthening the filament. The restoring force of the filament straightening against the surface delivers the propulsion force (Pollard and Borisy, 2003). Actin polymerization from plus ends at the leading edge of the lamellipodia is balanced by a myosin-powered, reaward movement of the lamellum actin meshwork known as retrograde flow (Cramer et al., 1997;Cramer, 1999;Rodriguez et al., 2003). In the cell body and its rear part actin forms contractile stress fibers responsible for the contraction of the cell body and retraction of the trailing edge (Etienne-Manneville, 2004). Several actin-binding proteins regulate the rate and organisation of actin polymerisation in protrusions (Ridley et al., 2003). The central role is played by proteins of the Rho GTPase family: RhoA, Rac, Cdc42 (Vicente-Manzanares et al., 2005). When bound to GTP, these proteins are active and interact with their downstream target proteins, which are protein kinases, lipid modifying enzymes, and activators of the Arp2/3 complexes. In addition to the actin cytoskeleton microtubules and ion channels play a significant role in cell migration.

\subsection{Role of Ion Channels in Cell Migration}

Ion channels are important biological macromolecules which are responsible for selective ion conductivity and tightly regulated. They are expressed in every cell and are essential for significant physiological processes such as sensory transduction, action-potential generation and muscle contraction. Numerous experiments during which channel activity was inhibited clearly show that ion channels are important for cell migration (Schwab et al., 1994;Schwab et al., 1999b;Jin et al., 2003;Schwab et al., 1999a;Schilling et al., 2004;Kim et al., 2004;Moreland et al., 2006;Munevar et al., 2004;Schwab et al., 2006). Blockade of ion channels slows migration down, inhibits chemotaxis, and transedothelial migration. The main explanation for such an observation is that ion channels take part in cell volume regulation (Schwab et al., 2006). Cell volume is modulated by ion channel activity and plays a critical role in the integrity of the actin cytoskeleton (Schwab et al., 2007). The polymerisation or depolymerisation of actin and tubulin filaments depends on the concentration of free monomers. When the concentration of free monomers than the critical concentration filaments grow, in reverse when the concentration of free monomers is less than critical concentration the filaments shrink (Alberts et al., 2002). Cell volume is also 
important for maintaining the appropriate cell shape. During migration the lamellipodium can protrude while the rear part of the cell is still attached (Fig. 1.1). Such changes in the shape of the cell must be supported by a precise volume regulation. In addition to setting the cell volume regulation ion channels are responsible for intracellular $\mathrm{Ca}^{2+}$ concentration. $\mathrm{Ca}^{2+}$ regulates the actin polymerisation and affects other critical proteins involved in cell migration. In the regulation of cell migration some families of ion channels are implicated: voltagegated potassium channels, calcium-activated potassium channels, chloride channels, voltage-gated sodium channels, aquaporins, mechanosensitive channels and ion exchangers such as: $\mathrm{Na}^{+} / \mathrm{H}^{+}, \mathrm{Cl}^{-} / \mathrm{HCO}_{3}{ }^{-},(\mathrm{NHE} 1, \mathrm{AE} 2), \mathrm{Na}^{+} / \mathrm{Ca}^{2+}$.

Here I concentrate on calcium-activated potassium channel ( $\left.\mathrm{K}_{\mathrm{Ca}} 3.1\right)$ (Ishii et al., 1997). The channel is expressed in many migrating cells, as well as leukocytes and tumour cells (Schwab et al., 2007;Eder, 1998;Jager et al., 2004;Kohler et al., 2003; Meyer et al., 1999;Ouadid-Ahidouch et al., 2004;Parihar et al., 2003;Schwab et al., 1993;Tajima et al., 2006). The inhibition of the channel sufficiently slows down cell migration (Jin et al., 2003;Schilling et al., 2004;Schwab et al., 1999a), quite the opposite heterologous expression speeds up those cells that do not contain endogenous channels (Schwab et al., 2006;Schwab et al., 2007). Topical application of channel blockers revealed that the channel is active only at the rear part of the cells (Schwab et al., 1995). Applying the activator of the channel causes the shrinkage of migrating cells at the their trailing edge (Schneider et al., 2000) supporting the hypothesis that $\mathrm{K}_{\mathrm{Ca}} 3.1$ channel is involved in the retraction of the rear part of the cell due to a local increase in the $\mathrm{Ca}^{2+}$ concentration (Fig. 1.3).

\subsection{Distribution and Recycling of $\mathrm{K}_{\mathrm{Ca}} 3.1$ Channel Proteins in Migrating Cells}

As mentioned earlier, $\mathrm{K}_{\mathrm{Ca}} 3.1$ channels are active at the rear part of the cell, while $\mathrm{Na}^{+} / \mathrm{H}^{+}$and $\mathrm{Cl}^{-} / \mathrm{HCO}_{3}{ }^{-}$exchangers are working at the front of the cell taking part in salt and osmotically obligated water uptake (Schwab et al., 1995;Klein et al., 2000; Schneider et al., 2000). The functional polarisation of $\mathrm{Na}^{+} / \mathrm{H}^{+}$and $\mathrm{Cl}^{-} / \mathrm{HCO}_{3}{ }^{-}$ exchangers is equivalent to the polarised distribution of NHE1 and AE2 proteins in migrating cells (Denker et al., 2000;Denker and Barber, 2002;Grinstein et al., 1993;Klein et al., 2000). Both exchangers are accumulated the leading edge of 
the cell. From the family of potassium channels, $\mathrm{K}_{\mathrm{v}} 1.4$ channels and $\mathrm{K}_{\mathrm{Ca}} 3.1$ channels are preferentially located at the leading edge (Reinhardt et al., 1998; Schwab et al., 2006). The difference between the functional activity of $\mathrm{K}_{\mathrm{Ca}} 3.1$ channels and their distribution in the cell membrane possibly can be explained by a variation in the intracellular $\mathrm{Ca}^{2+}$ concentration the rear part of the cell and at the lamellipodium and/or a difference in the intracellular location of channel regulators, for example, protein kinase C (Schwab et al., 2006).

It was proposed that newly synthesised $\mathrm{K}_{\mathrm{Ca}} 3.1$ channel proteins are delivered from the trans-Golgi network to the plasma membrane and that a the directed endocytic recycling of $\mathrm{K}_{\mathrm{Ca}} 3.1$ channels could contribute to their distinct subcellular distribution in migrating cells ((Schwab et al., 2006); Schwab unpublished observation). After insertion into the plasma membrane near the cell front the channel proteins may move within the plasma membrane towards the rear part of the cell, where they can be endocytosed and recycled to the cell front (Schwab, 2001). Such recycling was shown for $\beta_{2}$-integrins (Fabbri et al., 1999). Alternatively, the $\mathrm{K}_{\mathrm{Ca}} 3.1$ channel could be clustered by a linkage to the cytoskeleton. Then the $\mathrm{K}_{\mathrm{Ca}} 3.1$ channel should remain immobilized in the plasma membrane. However, so far there is no information available on the dynamics of $\mathrm{K}^{+}$channel molecules in the plasma membrane of motile cells.

Generally, several modes of plasma membrane protein motion can be observed: free, immobile, confined, tethered, resulting in normal diffusion, diffusion with directed motion, or anomalous diffusion as sub- and superdiffusion (Saxton and Jacobson, 1997). Migrating cells were the subject of intense studies on the detection of different types of lipid and protein motion in the plasma membrane during last thirty years (Bretscher, 1996). First, the phenomenon of antigen capping, crosslinking and moving to the trailing end of a migrating cell was observed (Taylor et al., 1971). This observation put in focus the motion of the plasma membrane and of special lipids in migrating cells. Bretscher (Bretscher, 1984) proposed a model of membrane flow that can drag the antigens. There is evidence supporting the model (Bretscher, 1984;Bretscher, 1996) but also contradicting it (Sheetz et al., 1989;Kucik et al., 1990;Lee et al., 1990). If there was a sufficient flow of lipids in the plasma 
membrane of migrating cells the mode of the channel protein motion should be a combination of diffusion and directed motion. The dynamics of $\mathrm{K}_{\mathrm{Ca}} 3.1$ channel proteins in the plasma membrane of migrating cells can be well characterised by applying the single molecule detection of $\mathrm{K}_{\mathrm{Ca}} 3.1$ channels and the tracking of the channel proteins during cell migration.

A

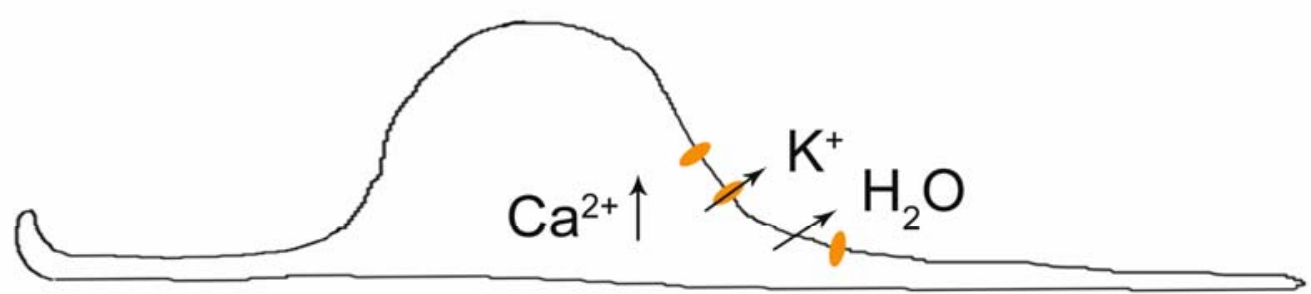

B

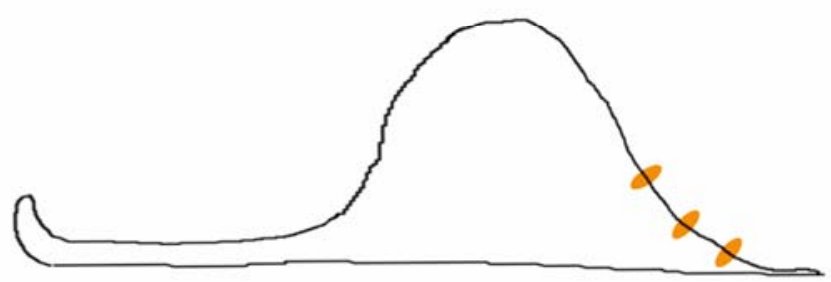

Figure 1.3 Activation of the Calcium-activated potassium channel $\mathrm{K}_{\mathrm{Ca}}$ 3.1. (A) Activation of the channel. A local increase in $\mathrm{Ca}^{2+}$ concentration leads to activation of $\mathrm{K}_{\mathrm{Ca}} 3.1$ channels which causes the efflux of $\mathrm{K}^{+}$and a loss of water. (B) Retraction of the rear part of the cell. The loss of water leads to the retraction of cell tail.

\subsection{Single Molecule Approach}

In recent years, the progress of single molecule technologies has renewed the way by which the biomolecules are studied. The novel instrumentation and techniques allow the characterization of single molecules, yielding new information on the dynamics of biomolecules by real-time observation of individual macromolecules and their complexes in the plasma membrane (Kusumi et al., 2005). 
A traditional way for studying dynamic processes in living cells used to be the fluorescence recovery after photobleaching (FRAP) (Verkman, 2003). The FRAP method uses the repetitive cycles of excitation and emission to bleach the fluorescent molecules that label the biological macromolecules at limited size area. By observating the upturn of macromolecules from unbleached surronding regions one can determine kinetic parameters such as the mobile fraction and the diffusion coefficient. Drawbacks of FRAP are (i) the insensitivity to separate subpopulations with different diffusion characteristics and (ii) the big observation area which is usually larger than the diffraction limit. One alternative to the FRAP method is the fluorescence correlation spectroscopy (FCS). FCS is based on the fluorescence intensity fluctuations associated with the molecules passing through a diffractionlimited observation volume. FCS can resolve translation diffusion of multiple subpopulations, well characterise molecular clustering and molecular concentrations. But important limitations of FCS are a low probe concentration and the complexity to determine the diffusion of slow-diffusing molecules such as membrane proteins. Another choice is the single particle tracking (SPT) (Saxton, 1997) (Fig. 1.4). SPT is a well suited method for the analysis of plasma membrane protein dynamics. It is based on the analysis of the trajectories of individual particles or fluorescent molecules. The method can characterise a transactional diffusion in different cell areas and has access to different modes of motion. It has an excellent spatial resolution (up to nanometers) and is limited by the frequency of image acquisition temporal resolution.

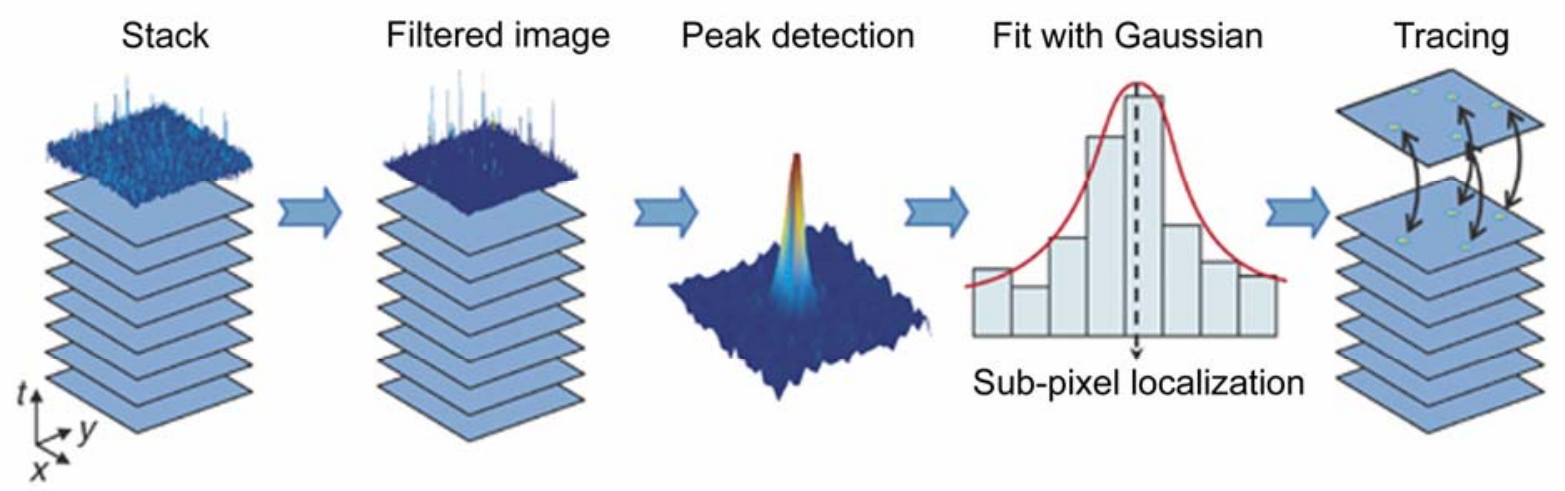

Figure 1.4 Single particle tracking. Particles are first detected in each image. The raw images are preprocessed (by performing deconvolution, noise reduction, spatial alignment) to enable an accurate determination of each peak position (Gauss-Newton fit). Particle tracing is then performed by connecting all the peak positions from frame to frame in order to draw space-time trajectories. Taken from (Marguet et al., 2006) 
To determine the trajectory of a plasma membrane protein in living cells it is necessary to label the protein molecule in an appropriate way. Gold particles are usually used to label the plasma membrane proteins on the apical side of the cell (Saxton and Jacobson, 1997). A typical gold particle has a size of up to $20 \mathrm{~nm}$. One important disadvantage of gold particles is the possible cross-linking of two or even more membrane proteins by antibodies or $F\left(a b^{\prime}\right)_{2}$ fragments on the surface of particles (Suzuki et al., 2005). Such a problem can be overcome by using green fluorescence protein (GFP) molecules as a dye for labelling of membrane proteins to be tracked or other inorganic molecules such as Alexa 488 or Cy5. Unfortunately, GFP molecules and organic dyes can bleach very quickly and it is not possible to track the labelled protein for a long time.

Another disadvantage is a low quantum yield which provides a low signal to noise ratio and consequently an uncertainty in position determination. Very often it is impossible to track single proteins labelled by organic dye due to a low intensity and a high level of autofluorescence of cell structures. Yet another task which is always critical in single molecule tracking is the confirmation of single molecule detection. For example, to confirm the single molecule detection the total integrated intensity versus time should be analysed. Each step on such a plot corresponds to one or more photobleaching events which finally can confirm the single molecule detection (Gordon et al., 2004). In case of GFP labbeled ion channels we should expect four steps. Such a complexity of the confirmation makes the single molecule approach very complicated or not even useful for cell physiology study.

In my view quantum dots (QDs) (Alivisatos AP, 1996;Michalet et al., 2005) allow the identification of $\mathrm{K}^{+}$channel proteins on the single molecule level by means of fluorescence microscopy. QDs were introduced as inorganic dyes, which in comparison with organic dyes are brighter, stable against photobleaching (Chan and Nie, 1998), and have narrow, tunable and symmetric emission spectra whose maxima depend on the size of QDs (Bruchez, Jr. et al., 1998) (Fig. 1.5). The QDs used in my study are composed of a core of cadmium selenide that is surrounded by a shell of zinc sulfide. Water solubility and attachement of QDs to biological molecules such as antibodies, lectins, or nucleic acids is mediated by a coating with 
organic molecules covalently attached to the surface of the shell. QDs are versatile dyes that are used in applications that range from labeling tumor cells within an organism (Voura et al., 2004) to studying the signaling cascade of epidermal growth factor in living $\mathrm{CHO}$ cells (Lidke et al., 2004).

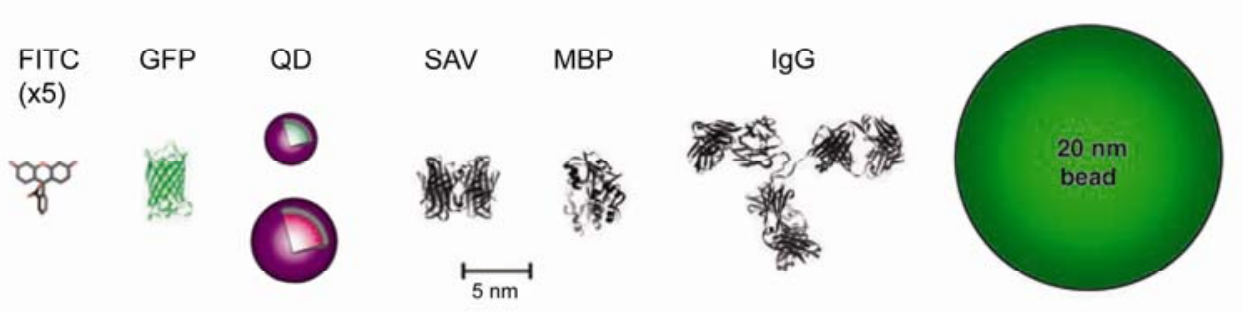

Figure 1.5 Size comparison of QDs and comparable objects. FITC, fluorescein isothiocyanate; GFP, green fluorescent protein; qdot, green ( $4 \mathrm{~nm}$, top) and red (6.5 nm, bottom) CdSe/ZnS QD; Three proteins-streptavidin (SAV), maltose binding protein (MBP), and immunoglobulin G (IgG) can be used for further functionalization of QDs and add to the final size of the QD, according to their solubilization chemistry. Adopted from (Michalet et al., 2005).

The ideal method for visualization and localisation of membrane proteins such as cellular receptors, adhesion foci of microtubules, and ion channels is the total internal reflection fluorescence (TIRF) microscopy (Schneckenburger, 2005) (Fig. 1.6) which provides the opportunity to excite fluorescent molecules in a layer of 100 $\mathrm{nm}$, in a cell near the substrate surface (Garini et al., 2005).

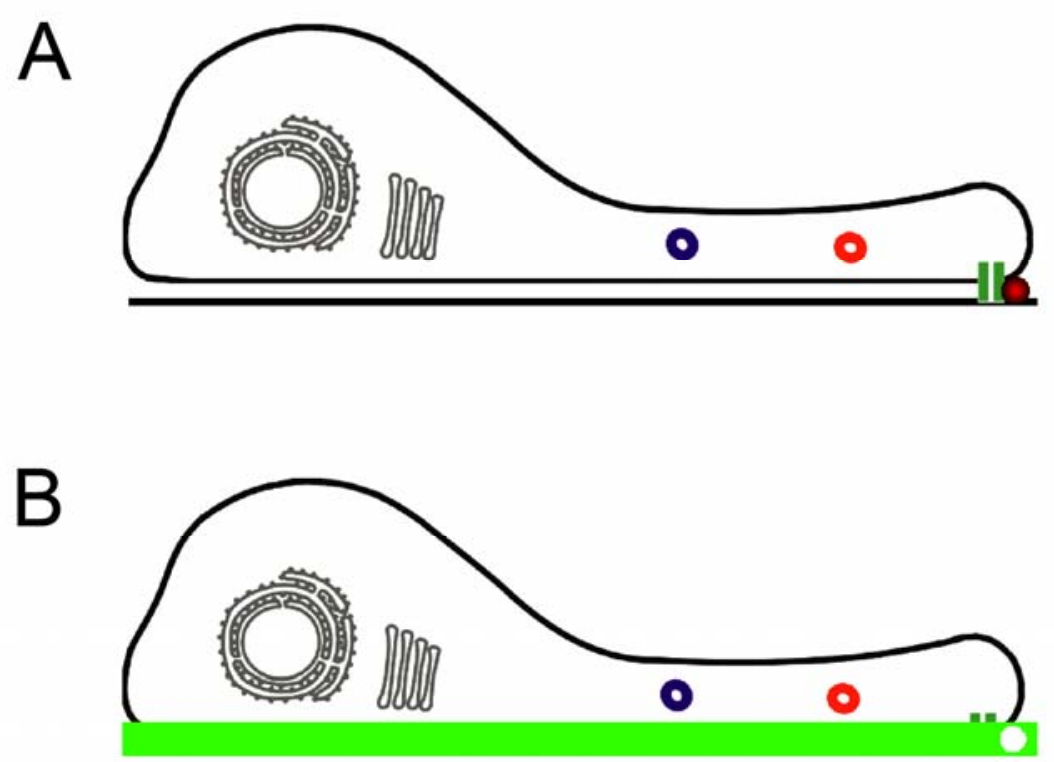

Figure 1.6 Total Internal Reflection Fluorescence Microscopy. (A) Labelling of the ion channel protein with a fluorescent molecule. (B) Visualization by means of TIRF. The excitation of fluorophore is induced by an evanescent wave or field in a limited specimen region $(100 \mathrm{~nm})$ immediately adjacent to the interface between two media having different refractive indices (glass and aqueous medium). 


\subsection{Aim}

$\mathrm{K}_{\mathrm{Ca}} 3.1$ is a calcium-activated potassium channel, which is essential for a proper cell migration. The channel proteins are found in the entire plasma membrane of migrating cells, but they are concentrated at the cell front. It was proposed that directed endocytic recycling of $\mathrm{K}_{\mathrm{Ca}} 3.1$ channels could contribute to this characteristic subcellular distribution in migrating cells. Alternatively, the $\mathrm{K}_{\mathrm{Ca}} 3.1$ channel could be clustered by linkage to the cytoskeleton. In this case the $\mathrm{K}_{\mathrm{Ca}} 3.1$ channel should be immobilized in the plasma membrane. However, so far there is no information available on the dynamics of $\mathrm{K}^{+}$channel molecules in the plasma membrane of motile cells. The aims set for this study were:

- To develop a method to identify single calcium activated potassium channel molecules in the plasma membrane of migrating cells.

- To study the dynamics of the channel protein in the plasma membrane of migrating cells. 


\section{Materials and Methods}

\subsection{Materials}

\subsubsection{Antibodies}

12CA5: Mouse monoclonal antibodies (clone 12CA5) to a peptide epitope derived from the hemagglutinin protein, were from Roche Diagnostics, Mannheim, Germany.

3F10: $\quad$ Rat monoclonal antibodies (clone 3F10) to a peptide epitope derived from the hemagglutinin protein of human influenza virus were from Roche Diangnostics, Manheim, Germany.

\subsubsection{Quantum Dot Conjugates}

QD565: Quantum dots (emmision $565 \mathrm{~nm}$ ) conjugate with goat $\mathrm{F}\left(a b^{\prime}\right)_{2}$ antimouse IgG was from Invitrogen, Hayward, USA.

QD655: Quantum dots (emmision $655 \mathrm{~nm}$ ) conjugate with goat $F\left(a b^{\prime}\right)_{2}$ antimouse IgG was from Invitrogen, Hayward, USA.

\subsubsection{Cell Lines}

MDCK-F Cell Line: Alkaline stress transforms Madin-Darby canine kidney cell line.

MDCK-F-5B8 Cell Line: MDCK-F cell line transfected with a modified human isoform of calcium-activated potassium channel 3.1 ( $\left.\mathrm{hK}_{\mathrm{Ca}} 3.1\right)$ containing an $\mathrm{HA}$ tag in the extracellularly located S3-S4 linker (Schwab et al., 2006).

\subsubsection{Apparatus}

Abimed, Düsseldorf, Germany 
Gilson Pipetman $2 \mu \mathrm{l}, 20 \mu \mathrm{l}, 200 \mu \mathrm{l}, 1000 \mu \mathrm{l}, 5000 \mu \mathrm{l}$

Carl-Zeiss GmbH, Jena, Germany

Fluorescence microscope, Axiovert 200

Chroma Technology Corp., Rockingham, USA

Filters:

$\mathrm{z} 488 / 10$

BP $525 / 50$

Dichroic Mirror:

z488RDC

Forma Scientific, Inc., Waltham, USA

Forma Scientific-Biofreezer $\left(-80^{\circ} \mathrm{C}\right)$

Haake, Karlsruhe, Germany

Waterbath Haake DC1

Kalr Hecht KG, Sondheim, Germany

Glass cover slips

Mettler, Bach, Germany

Balance PC 2000

Thermo Electron Corporation, Waltham, USA

HERA-Cell $150 \mathrm{CO}_{2}$ / water incubator for cell culture

TILL Photonics, Gräfelfing, Germany

TIRF slider, Argon laser

Omega Optical Inc., Baltimore, USA

Filters:

XF302-1 
XF305-1

Dichroic Mirror

545DRLP

Privileg, Quelle, Nürnberg, Germany

Privileg Öko Refrigerator and freezer

Renner GmbH, Darmstadt, Germany

Single-used yellow and blue tips

Pasteur-pipettes

Sartorius AG, Göttingen, Germany

Balance MC1 research RC $210 P$

Schott, Jena, Germany

Schott flask, glass beaker

\subsubsection{Chemicals}

All chemicals if not mentioned are of p.A. quality from E. Merck AG, Darmstadt, Germany; Carl Roth $\mathrm{GmbH}$ \& Co, Karlsruhe, Germany and Serva, Heidelberg, Germany.

Sigma-Aldrich, Munich, Germany

Ethanol, Ethylenediamine tetraacetic acid (EDTA), Glutaraldehyde, 4-(2hydroxyethyl)-1-piperazineethanesulfonic acid (HEPES), Magnesium chloride, Sodium chloride, Geneticin.

Biochrom KG, Berlin, Germany

Fetal Bovine Serum (FBS)

PAA, Pasching, Austria

Minimal Essential Medium (MEM), L-15 Medium (Leibovitz's), Phosphate-buffered salt solution (PBS) with $\mathrm{Ca}^{2+}$ and $\mathrm{Mg}^{2+}$. 


\subsubsection{Computer Programs}

\begin{tabular}{|c|c|c|}
\hline Program & Manufacturer & Application \\
\hline Word $\AA$ & Microsoft, London, UK & Text \\
\hline SigmaPlot $2000 \circledR$ & SPSS Inc., Chicago, USA & Diagrams and statistics \\
\hline MATLAB R2006a® & $\begin{array}{l}\text { MathWorks Inc., Natick, } \\
\text { USA }\end{array}$ & Homemade routines \\
\hline 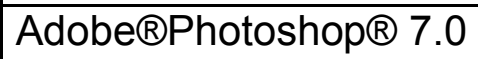 & Adobe Inc., San Jose, USA & Figure preparation \\
\hline MetaView $®$ & $\begin{array}{l}\text { Universal Imaging Cor., } \\
\text { Downingtown, USA }\end{array}$ & Image acquisition \\
\hline MetaMorph® & $\begin{array}{l}\text { Universal Imaging Cor., } \\
\text { Downingtown, USA }\end{array}$ & Image analysis \\
\hline ImageJ & $\begin{array}{l}\text { National Institute of Health, } \\
\text { USA }\end{array}$ & Image sequence import \\
\hline AMIRA® & $\begin{array}{l}\text { TGS Inc., San Diego, CA, } \\
\text { USA }\end{array}$ & $\begin{array}{l}\text { The cell contours } \\
\text { determination }\end{array}$ \\
\hline Spot Tracker 2D & $\begin{array}{l}\text { Biomedical Imaging Group, } \\
\text { Lausanne,Switzerland }\end{array}$ & $\begin{array}{l}\text { Determination of position } \\
\text { of the fluorescence } \\
\text { molecules }\end{array}$ \\
\hline
\end{tabular}

\subsection{Methods}

\subsubsection{Cell Culture}

MDCK-F cells were cultured in Minimum Essential Medium (MEM; pH 7.4) medium. FBS $(10 \%)$ was added to provide growth factors. Cells were grown in a $\mathrm{CO}_{2}$ incubator (Thermo Electron Corporation, Langenselbold, Germany) at $37^{\circ} \mathrm{C}$ and $5 \%$ $\mathrm{CO}_{2}$ with $95 \%$ humidity. For cultivation of MDCK-F-5B8 cells MEM was additionally supplemented with $600 \mathrm{mg} / \mathrm{ml}$ geneticin. Cells were seeded on poly-L-lysine coated glass cover slips for experiments. 


\subsubsection{Immunofluorescence Labeling}

\subsubsection{Fixed Cells}

MDCK-F cells were fixed with $0.5 \%$ glutaraldehyde in HEPES-buffered Ringer's solution ( $\mathrm{pH} \mathrm{7.4)}$ ) for 45 minutes directly in the incubator in order to preserve the intact architecture of the lamellipodium and the ruffled membrane at its leading edge. After fixation the cells were washed five times in PBS $(\mathrm{pH} \mathrm{7.4)}$ at room temperature, and kept in $100 \mathrm{mM}$ glycine/PBS solution for 30 minutes. After washing cells were blocked with FBS (10\% in PBS) for one hour at room temperature, and incubated with primary antibodies against the extracellular $\mathrm{HA}$ tag of $\mathrm{hK}_{\mathrm{ca}} 3.1$ channels (1:600) for one hour at room temperature. Antibody specificity was confirmed previously by western blotting (Schwab et al., 2006). Then the cells were again washed five times in PBS. For one-colour labeling I incubated the cells with goat $F\left(a b^{\prime}\right)_{2}$ anti-mouse IgG conjugated with QDs (1:50) for one hour at room temperature, and for multicolour labeling with a mixture of QD565 and QD655 goat $F\left(a b^{\prime}\right)_{2}$ anti-mouse IgG conjugates (1:25 and 1:100, respectively), for one hour at room temperature. Titers of secondary antibodies were chosen such that QD565 and QD655 labeled the cells at a similar density. Moreover, care was taken that the total density of QDs was low enough to clearly identify them individually. The cells were again washed five times in PBS and fixed by $0.5 \%$ glutaraldehyde in HEPES buffer ( $\mathrm{pH} 7.4$ ) for 45 minutes.

HEPES-buffered Ringer's solution (pH 7.4)

$10 \mathrm{mM}$ Hepes

$122.5 \mathrm{mM} \mathrm{NaCl}$

$5.4 \mathrm{mM} \mathrm{KCl}$

$0.8 \mathrm{mM} \mathrm{MgCl} 2$

$1.2 \mathrm{mM} \mathrm{CaCl}_{2}$

$1.0 \mathrm{mM} \mathrm{NaH}_{2} \mathrm{PO}_{4}{ }^{*} \mathrm{H}_{2} \mathrm{O}$

$5.0 \mathrm{mM}$ Glucose

2.2.2.1 Living Cells
PBS (pH 7.4)

$137 \mathrm{mM} \mathrm{NaCl}$

$2.7 \mathrm{mM} \mathrm{KCl}$

$4.3 \mathrm{mM} \mathrm{Na}_{2} \mathrm{HPO}_{4}$

$1.4 \mathrm{mM} \mathrm{KH} \mathrm{PO}_{4}$ 
MDCK-F cells were cultured in Leibowitz Medium L-15 (Leibovitz, 1969) (pH 7.1) with FBS (10\%) on poly-L-lysine coated glass cover slips for $12 \mathrm{~h}$ before antibody labeling at $37{ }^{\circ} \mathrm{C}$. The cells were incubated with primary rat antibodies (3F10) against the extracellular $\mathrm{HA}$ tag of $\mathrm{hK}_{\mathrm{Ca}} 3.1$ channels (1:900) for 15 minutes, briefly washed (at $37^{\circ} \mathrm{C}$ ) and then washed three times for 5 min in L-15 medium with FBS (10\%). Thereafter, cells were incubated with QD655 (1:1000), for 15 minutes at 37 ${ }^{\circ} \mathrm{C}$. Titers of secondary antibodies were chosen such that the total density of QDs was low enough to clearly track them individually. Then the cells were again washed as described above and the cover slip was positioned in a heated chamber $\left(37^{\circ} \mathrm{C}\right)$ for microscopic observation.

\subsubsection{Microscopy and Data Acquisition}

\subsubsection{Fixed Cells}

Immunofluorescence microscopy was performed with an inverted microscope (Axiovert 200, Zeiss, Oberkochen, Germany) equipped with a digital camera (Visitron, Puchheim, Germany) and a 100x1.45 oil immersion objective. Data acquisition and analysis was performed by the Metavue software (Visitron). I used the following filters: QD565, $420 \mathrm{~nm}$ excitation, emission $565 \mathrm{~nm}$ (XF302-1 filter; Omega Optical, Brattleboro, USA); QD655, 420 nm excitation, emission 655 nm (XF305-1 filter; Omega Optical). The number of QDs per cell was corrected for background level of QDs determined in cell-free areas. In case of double colour labeling only those cells were taken for further analysis in which the numbers of green and red QDs were the same. The pixel with the highest fluorescence intensity was taken as the optical center of a QD. Distance between QDs was then measured as the distance of their optical centers. Pixel shift due to filter change was determined by acquiring two images of QD labeled cells in one channel with a filter change (for example red-green-red) in between. The two images were assigned to different colours, superimposed, and the distances of the optical centers were determined. The mean pixel shift amounted to $0.46 \pm 0.05$ pix ( $N=100$ QD pairs). 


\subsubsection{Living Cells}

MDCK-F cells were kept in L-15 medium throughout the course of the experiment. They were observed with an inverted microscope (Axiovert 200, Zeiss, Oberkochen, Germany) equipped with a digital camera (Visitron, Puchheim, Germany), TIRF slider (TILL Photonics, Gräfelfing, Germany) and a 100x1.45 oil immersion objective. Data acquisition was controlled by the Metavue software (Visitron). Cell movement was monitored for 10 minutes before TIRF microscopy by acquiring brightfield images in $20 \mathrm{~s}$ intervals. The initial observation of the migration was followed immediately by monitoring the dynamics of $\mathrm{K}_{\mathrm{Ca}} 3.1$ channels with TIRF microscopy. QDs that labeled individual $\mathrm{K}_{\mathrm{Ca}} 3.1$ channels were excited with an argon laser (TILL Photonics) at a wavelength of $488 \mathrm{~nm}$. I used the following filters for QD656: z488/10 (excitation) (Chroma Technology Corp., Rockingham, USA), 545DRLP (dichroic mirror) (Omega Optical Inc., Brattleboro, USA), XF305-1 (emission) (Omega Optical). Stacks of 50 images were acquired in $\Delta=600 \mathrm{~ms}$ time intervals with a shutter (exposure) time of $\eta=200 \mathrm{~ms}$.

\subsubsection{Analysis of Cell Migration}

The boundaries of the cells were labeled employing AMIRA software (TGS Inc., San Diego, CA, USA). The cell contours then served as the basis for analyzing cell migration. The migratory speed was analyzed calculated as the movement of the cell center from a there point difference quoting by using self-made JAVA programs and the NIH ImageJ software (http://rsb.info.nih.gov/ij/) (Schwab et al., 2006). The displacement represents the distance covered by the cell center within a time period of $10 \mathrm{~min}$.

\subsubsection{Tracking of $\mathrm{K}_{\mathrm{Ca}} 3.1$ Channels}

The $\mathrm{x}$-, and $\mathrm{y}$ - coordinates of individual $\mathrm{K}_{\mathrm{Ca}} 3.1$ channels were determined in each image of the stack with the ImageJ pugin Spot Tracker 2D (Sage et al., 2005). Trajectories were constructed from these data sets, which were the basis of further analysis. I assessed the accuracy of the QD localization by tracing immobile QDs that were attached to the glass surface in cell free areas during data acquisition $\left(N_{\text {QDimmobile }}=11\right)$. This delivered an uncertainty of position measurement of $\varepsilon \sim 0.03$ $-0.04 \mu \mathrm{m}$ per direction (Supplemental Material Fig. 1). 


\subsubsection{Analysis of $\mathrm{K}_{\mathrm{Ca}} 3.1$ Dynamics}

I either pooled all trajectories from all cells or I grouped them according to their localization in one of the four regions. These regions were defined according to the following criteria: the leading edge (membrane within 5-10 $\mu \mathrm{m}$ from the cell front), lamellipodium (membrane between the leading edge and the cell body), cell body (membrane surrounding the nucleus and other organelles), and the region of the uropod (see Figure 3.4C). The mean squared displacement was calculated for each group of paths. It describes the mean of the squared distances between a common starting point at time $t_{0}$ and a later position at time $t$. It is defined as

$$
\operatorname{msd}(t)=\left\langle\left(x(t)-x\left(t_{0}\right)\right)^{2}+\left(y(t)-y\left(t_{0}\right)\right)^{2}\right\rangle
$$

where $x$ and $y$ denote the positions of the QDs at observation time $t$ in the twodimensional plane. $<\ldots>$ marks a combined average over all starting times $t_{0}$ and all paths. The time-dependent behavior of the mean squared displacement characterizes the dynamic behavior of the $\mathrm{K}_{\mathrm{C} a} 3.1$ channels. The $m s d(t)$ often shows a power-law scaling over a certain time range that can be written as model equation

$$
\operatorname{msd}(t)_{\bmod }=4 D_{\alpha} t^{\alpha}
$$

for a two-dimensional process. $D_{\alpha}$ represents the diffusion coefficient depending on the coefficient $\alpha$. $\alpha$ corresponds to the slope of $m s d(t)$ in the double logarithmic plot. The parameter $\alpha$ allows to distinguish between normal diffusion ( $\alpha=1)$, subdiffusion $(\alpha<1)$, and super-diffusion $(\alpha>1)$. In the case of a collective drift (i.e. in our case due to directed transport, or movement of the entire cell), equation (F2) may be modified by an additional term $v_{\text {drift }}^{2} t^{2}$.

As shown by Savin and Doyle (Savin and Doyle, 2005) static and dynamic measurement errors modify the apparent experimental result. According to these authors (Savin and Doyle, 2005) a modification of (F2) has to be made in order to incorporate the dynamic measurement error which is due to a finite shutter time $\eta=$ $200 \mathrm{~ms}$ that is in the same order of magnitude as the time interval of image acquisition $\Delta=600 \mathrm{~ms}$ :

$$
\operatorname{msd}(t)_{\bmod }^{*}=4 D_{\alpha} \frac{\eta^{\alpha}}{(1+\alpha)(2+\alpha)}\left[\left(\frac{t}{\eta}+1\right)^{2+\alpha}+\left(\frac{t}{\eta}-1\right)^{2+\alpha}-2\left(\frac{t}{\eta}\right)^{2+\alpha}-2\right]
$$


If shutter times $\eta$ are much smaller than the interval between two exposures $(\eta<<), m s d(t)^{*}{ }_{m o d}$ will practically reduce to the simpler form of (F2). However, in our case the relatively long shutter time $\eta$ generates a dynamic error that induces an apparent superdiffusive behavior for small times (Savin and Doyle, 2005). This error can be eliminated by the usage of (F3).

$\mathrm{K}_{\mathrm{Ca}} 3.1$ channel dynamics can also be characterized by calculating higher moments of the probability functions $p(x, t)$, i.e the so-called second moment. For example, the kurtosis is defined as the ratio of the forth and the squared second moment

$$
\kappa_{x}(t)=\left\langle\left[x(t)-x\left(t_{0}\right)\right]^{4}\right\rangle /\left\langle\left[x(t)-x\left(t_{0}\right)\right]^{2}\right\rangle^{2}
$$

of the data in $x$ and $y$ direction, respectively. For a normally diffusive process where the particles spread with Gaussian probability functions $p(x, t)$, the kurtosis has a value of 3 . Deviations form a value of 3 indicate anomalous non-Gaussian dynamics.

\subsubsection{Estimation of Ion Channel Drift and Relative Error}

In order to estimate the possible common drift of all ion channels in the plasma membrane random walk simulation was performed with simulated drift in one direction $\left(v_{\text {simulated_drift }}\right)$. Next parameters were used for simulation: $N_{\text {lon }}$ Channels $=80$, $L_{\text {Number of Steps }}=50, d t=0.6 \mathrm{~s}, D=0.06 \mu \mathrm{m}^{2} / \mathrm{s}$. The obtained trajectories were analysed according to equation (F2) with additional term $v_{d r i f t}^{2} t^{2} \cdot v_{d r i f t}$ was estimated and compared with velocity of simulated drift $\left(v_{\text {simulated_drift }}\right)$. Relative error $\left(v_{\text {drift }} / v_{\text {simulated_drift }}\right)$ was also calculated for different values of simulated drift.

\subsubsection{Statistics}

Data are presented as the mean values \pm standard deviation of the mean, unless stated otherwise. Bayesian probability theory was applied for fitting the msd function (F3) to the msd (F1) obtained from experimentally measured data. This approach (Jaynes, 2003) was used to estimate the values of the parameter $\alpha$ and $D_{\alpha}$ of the msd model. 


\section{Results}

\subsection{Detection of Single Potassium Channel Proteins}

When the distribution of the $\mathrm{hK}_{\mathrm{Ca}} 3.1$ channel in the plasma membrane of MDCK-F$5 B 8$ cells is visualized with QD labeling (Fig. 3.1) the overall staining is similar to previous results obtained with conventional fluorescence labeling (Schwab et al., 2006). The potassium channels are more concentrated at the leading edge of the cell than in the remaining membrane of the lamellipodium. The average density of QDs amounts to $\sim 2 \mathrm{QDs} / \mu^{2}{ }^{2}$ which is similar to the channel density calculated from earlier patch clamp studies.

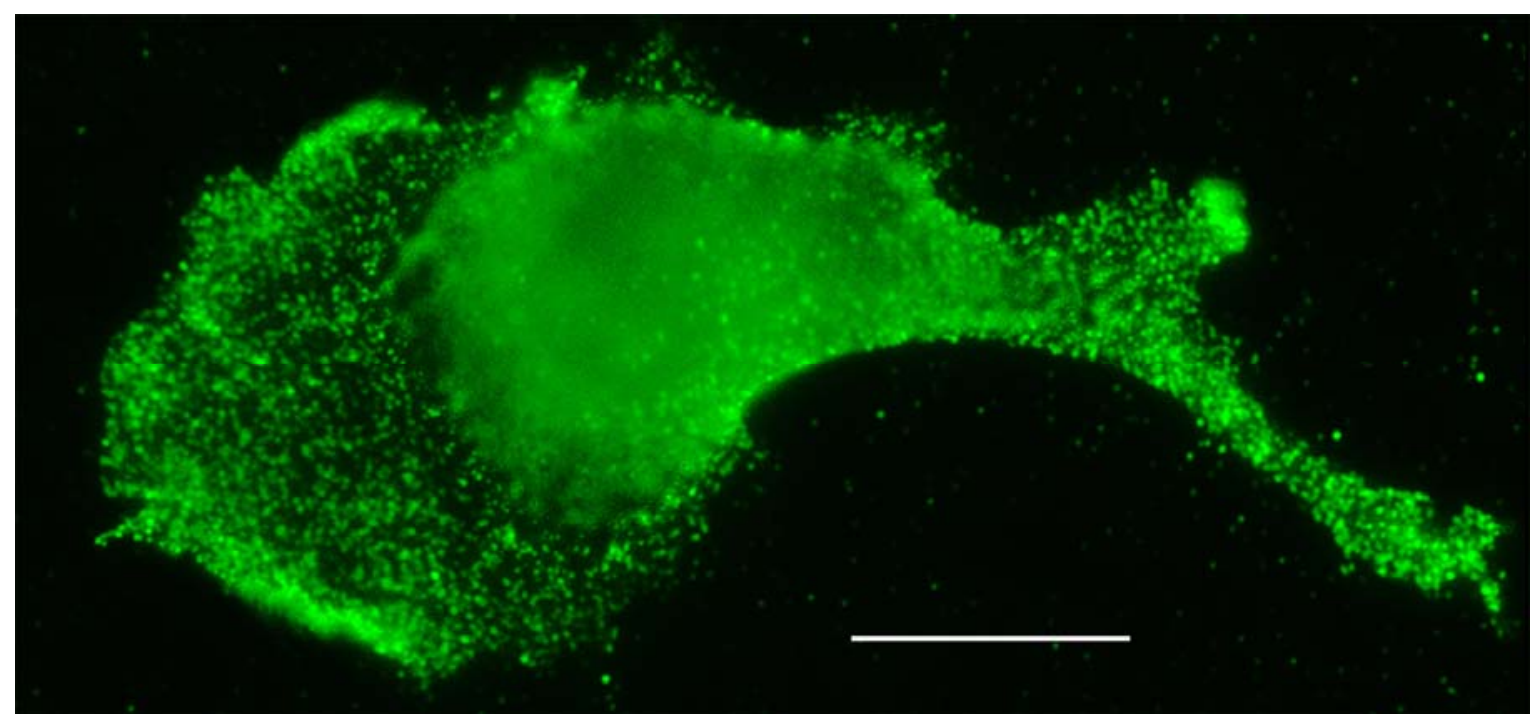

Figure 3.1: Detection of $\mathrm{hK}_{\mathrm{Ca}} 3.1$ channels on the surface of a MDCK-F-5B8 cell by QD labeling. The green spots correspond to $\mathrm{hK}_{\mathrm{Ca}} 3.1$ channel proteins labeled with QD565. The diffuse staining of the cell center is due to glutaraldehyde autofluorescence. Bar: $15 \mu \mathrm{m}$. (Nechyporuk-Zloy et al., 2006)

To verify that a single QD corresponds to a single channel and not to a group of single channels I applied dual-colour labeling. I added a mixture of secondary antibodies conjugated either with "red" QDs that emit at 655 nm (QD655) or with "green" QDs that emit at $565 \mathrm{~nm}$ (QD565) (Fig. 3.2A,B). The titers of the secondary antibodies were adjusted in such a way that they bind with the same efficacy to their target. Consequently, the numbers of QD655 and QD565 per cell are the same (Fig. 3.3). The merged cell surface image (Fig. 3.2A, B) exhibits many green (QD565) and red (QD655) and only a small fraction of "yellow" spots. Red and green spots could either represent single QD's marking individual channel proteins, or the binding of several red (QD655) 
or green (QD565) QDs to one channel protein. The appearance of yellow spots in the merged image indicates that red (QD655) and green (QD565) QDs are binding to the potassium channel simultaneously. The intensity profile (Fig. 3.2C) provides a quantitative analysis. Two pairs of red and green QDs are shown. Their optical centers are only 1 - 2 pixels or $60-120 \mathrm{~nm}$ apart from each other. It is only by the use of the dual labeling technique that these QDs can be recognized individually. This would not be possible in case of single colour labeling. They would look like one bright single QD. However, most spots are clearly red or green and only a small fraction of spots $(3.3 \%)$ is yellow with different distances between optical centers (Fig. 3.3). The fraction of yellow spots is hardly affected by doubling the antibody concentrations. 

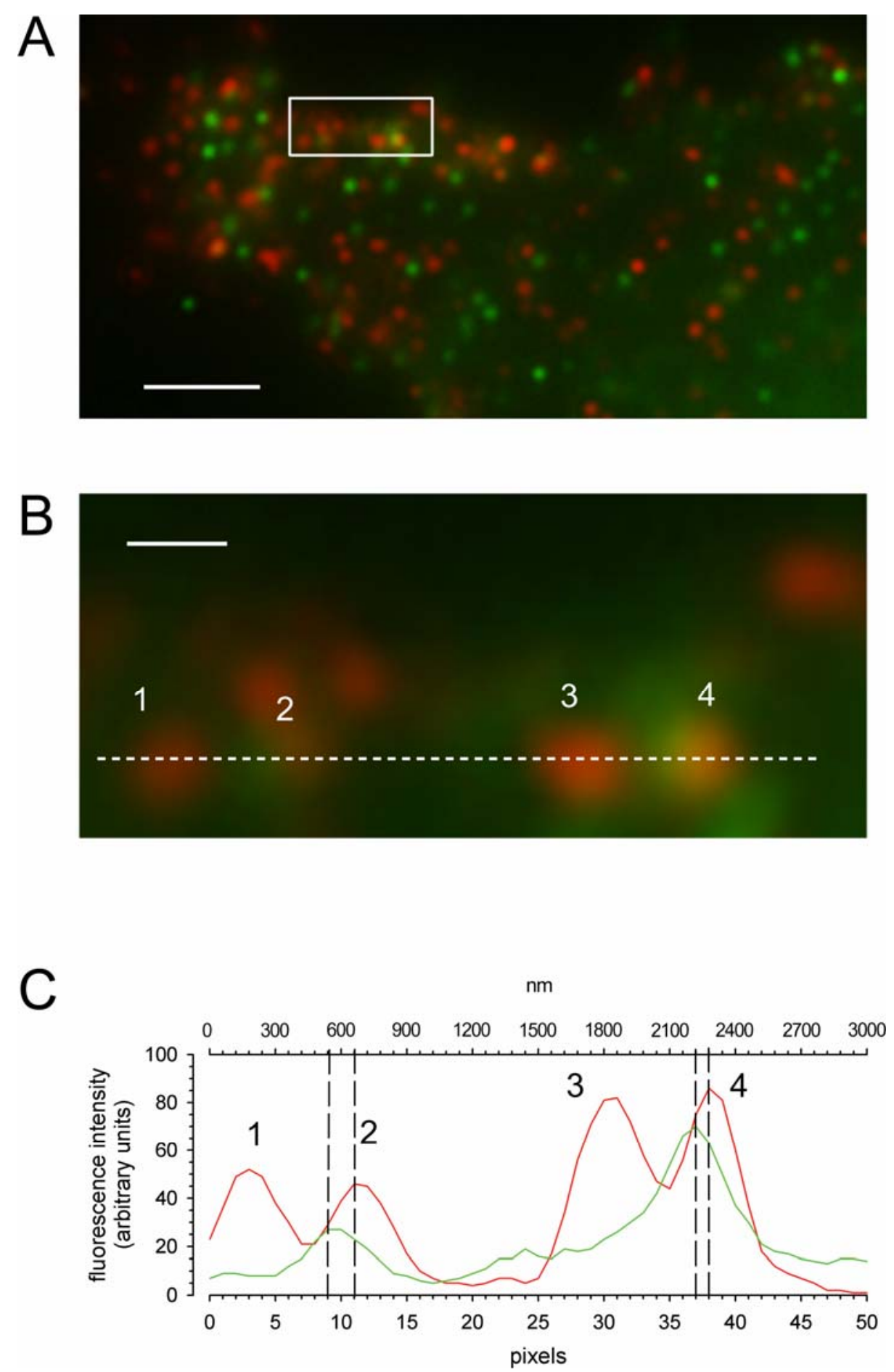

Figure 3.2: Multicolour QD labeling of $\mathrm{hK}_{\mathrm{Ca}} 3.1$ channel on the surface of a MDCK-F-5B8 cell. (A) Leading edge and lamellipodium of the cell. Green and red spots correspond to single $\mathrm{hK}_{\mathrm{Ca}} 3.1$ channel proteins. Yellow spots indicate dual labeling with a pair of QD565 and QD655 with a distance of 1-2 pixels between their optical centers. A magnified view of the white rectangle is seen in panel B. Bar: $3 \mu \mathrm{m}$. (B) Leading edge of the cell. The dashed white line marks four spots, whose intensity profiles are shown in panel C. Spots 1 and 3 are only labeled by red QD655 while spots 2 and 4 are dually labeled with green QD565 and red QD655 and therefore appear yellow. Bar: 0.5 $\mu \mathrm{m}$. (C) Intensity profile of fluorescence signal. Vertical dashed lines mark the optical centers of fluorescence signal from single QDs which are located closely to each other. (Nechyporuk-Zloy et al., 2006) 


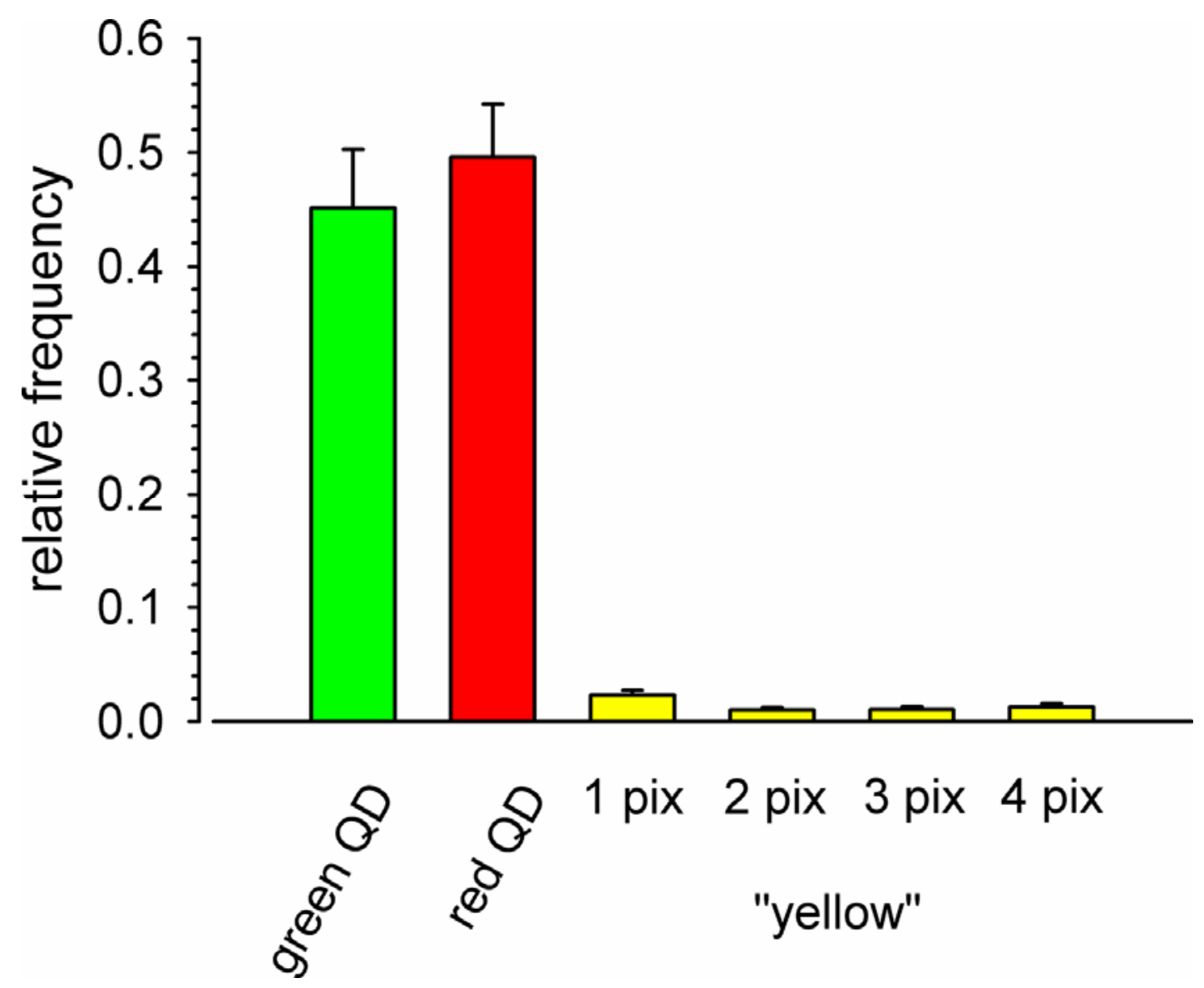

Figure 3.3: Relative frequency of dual-colour QD binding to $h K_{\mathrm{Ca}} 3.1$ channel proteins. The bars marked with "yellow" give the frequencies of labeling $\mathrm{hK}_{\mathrm{Ca}} 3.1$ channel proteins with green QD565 and red QD655 simultaneously. The distances of the optical centers of the QDs are indicated. Data are presented as the mean values \pm standard error mean. $N=14$ MDCK-F-5B8 cells. (Nechyporuk-Zloy et al., 2006) 


\subsection{Dynamics of Single Potassium Channel Proteins}

I had shown in my previous study that individual $\mathrm{K}_{\mathrm{Ca}} 3.1$ channels can be visualized with QD labeling technology (Nechyporuk-Zloy et al., 2006). Each channel protein binds only one QD antibody conjugate. Thus the movement of QD can be taken as an approximation of the channel movement. After the labelling procedure and prior to imaging the dynamics of $\mathrm{K}_{\mathrm{Ca}} 3.1$ channels with TIRF microscopy MDCK-F cells moved with a speed of $0.56 \pm 0.06 \mu \mathrm{m} / \mathrm{min}$ (10 cells) (Fig. 3.4A) (Supplemental material: Movie 1).

Fig. 3.4B demonstrates that the channel proteins were labeled over the entire basal plasma membrane with no preference for the cell periphery. That is, QDs had free access to the lower surface of MDCK-F cells so that they could be imaged with TIRF microscopy. The specifity of the $\mathrm{K}_{\mathrm{Ca}} 3.1$ channel labeling was verified by staining MDCK-F cells with secondary QD655-conjugated antibodies only or by the use of wild type MDCK-F cells that do not express the modified $\mathrm{hK}_{\mathrm{Ca}} 3.1$ channel. In both cases I only observed a maximum of 2-3 QDs per visual field that were attached unspecifically to the cell surface or to the glass cover slip. This number is negligible when compared to the number of approximately $100 \mathrm{~K}_{\mathrm{Ca}} 3.1$ channels labelled with QDs in the plasma membrane of a MDCK-F cell.

Figure $3.4 \mathrm{C}$ shows the typical paths of $\mathrm{hK}_{\mathrm{Ca}} 3.1$ potassium channel proteins in the plasma membrane of a migrating MDCK-F cell (Supplemental material: Movie 2). It is evident that the movement of $\mathrm{K}_{\mathrm{Ca}} 3.1$ channels is very heterogeneous. Some channels cover relatively long distances (up to $6.3 \mu \mathrm{m}$ within $30 \mathrm{~s}$ ) (Fig. 3.5A (trajectory 2), Fig. 3.5B (trajectory 2)) while some are more or less stationary (Fig. 3.5A (trajectory 1), Fig. 3.5B (trajectory 1 )). The average distance covered by $\mathrm{K}_{\mathrm{Ca}} 3.1$ channels within $30 \mathrm{~s}$ is about $2.1 \mu \mathrm{m}$ (given as square root of the corresponding $\mathrm{msd}$ value). The average displacement of the entire cell within the same time period amounts to $\sim 0.3 \mu \mathrm{m}$. Hence, the movement of $\mathrm{K}_{\mathrm{Ca}} 3.1$ channels is almost one order of magnitude faster than the movement of MDCK-F cells. Figure 3.5C indicates $\mathrm{K}_{\mathrm{Ca}} 3.1$ channels in the plasma membrane of the same cell have no preferential direction of motion. 


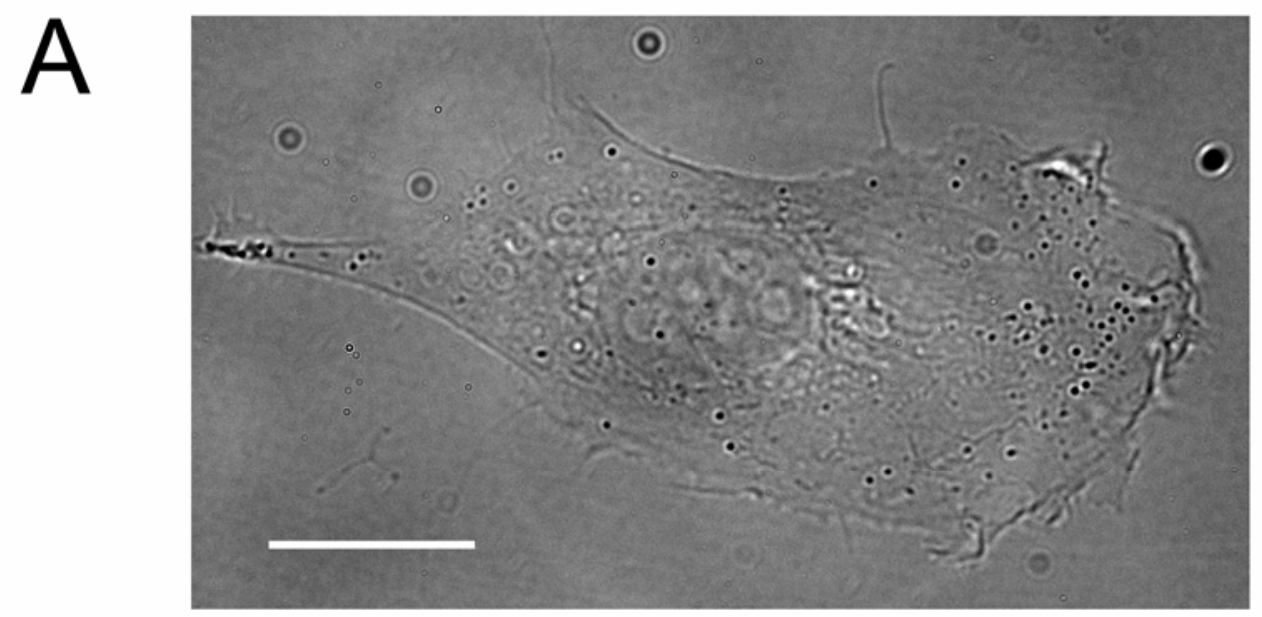

B
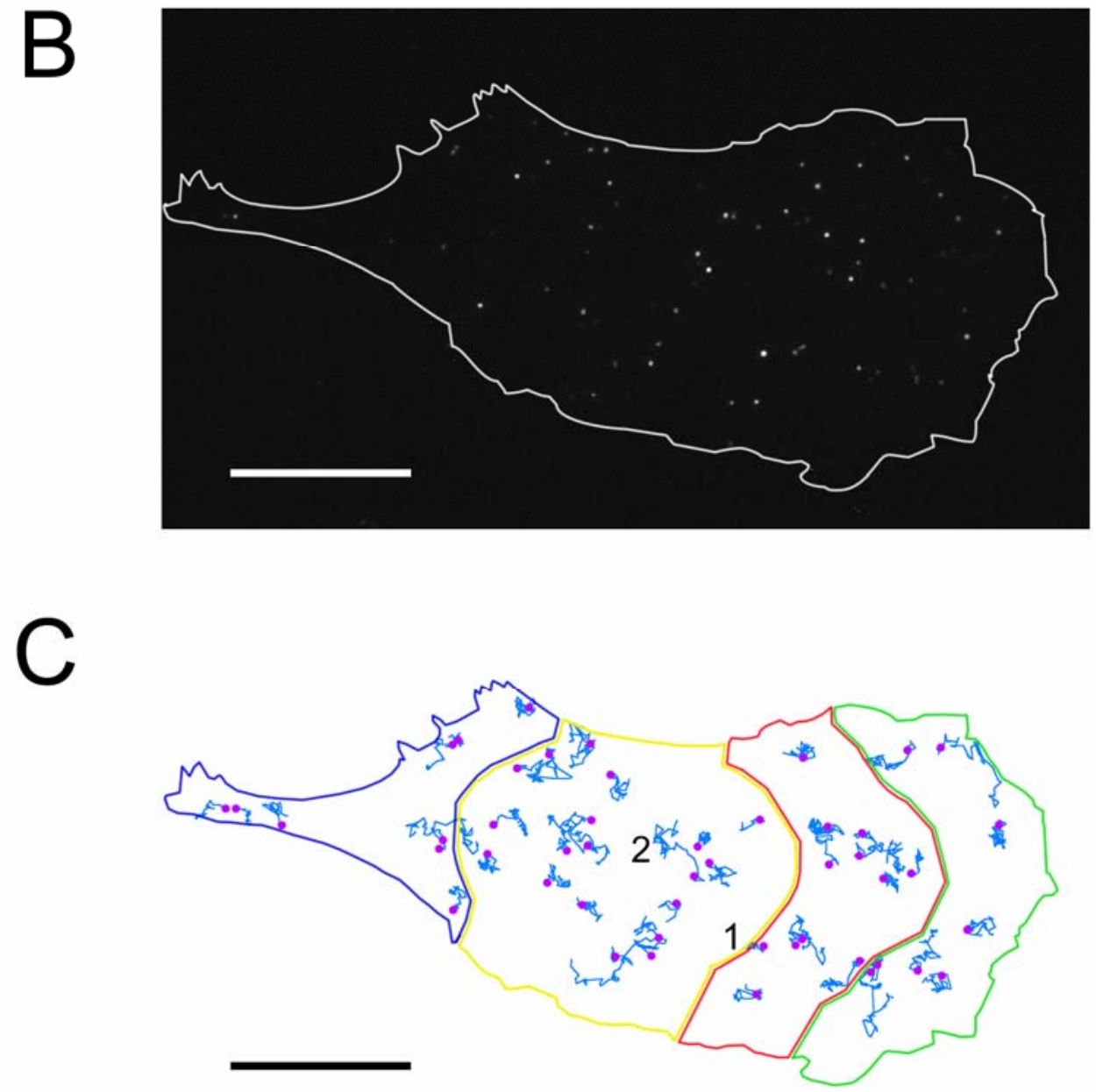

Figure 3.4: Time-lapse TIRF microscopy imaging of $\mathrm{hK}_{\mathrm{Ca}} 3.1$ channels in the plasma membrane of a migrating MDCK-F cell by QD labeling. (A) Transparent image of MDCK-F cell before time-lapse TIRF microscopy imaging. (B) Initial frame of TIRF microscopy image. QDs are seen as white dots. Lateral cell borders appear white. (C). QDs trajectories. The plasma membrane is divided on four regions: leading edge (green), lamellipodium (red), cell body (orange), uropod (blue). Two trajectories $(1,2)$ are shown in details on Fig. 3.5. In (A, B, C), the scale bars represent $15 \mu \mathrm{m}$. (Nechyporuk-Zloy et al., submitted) 

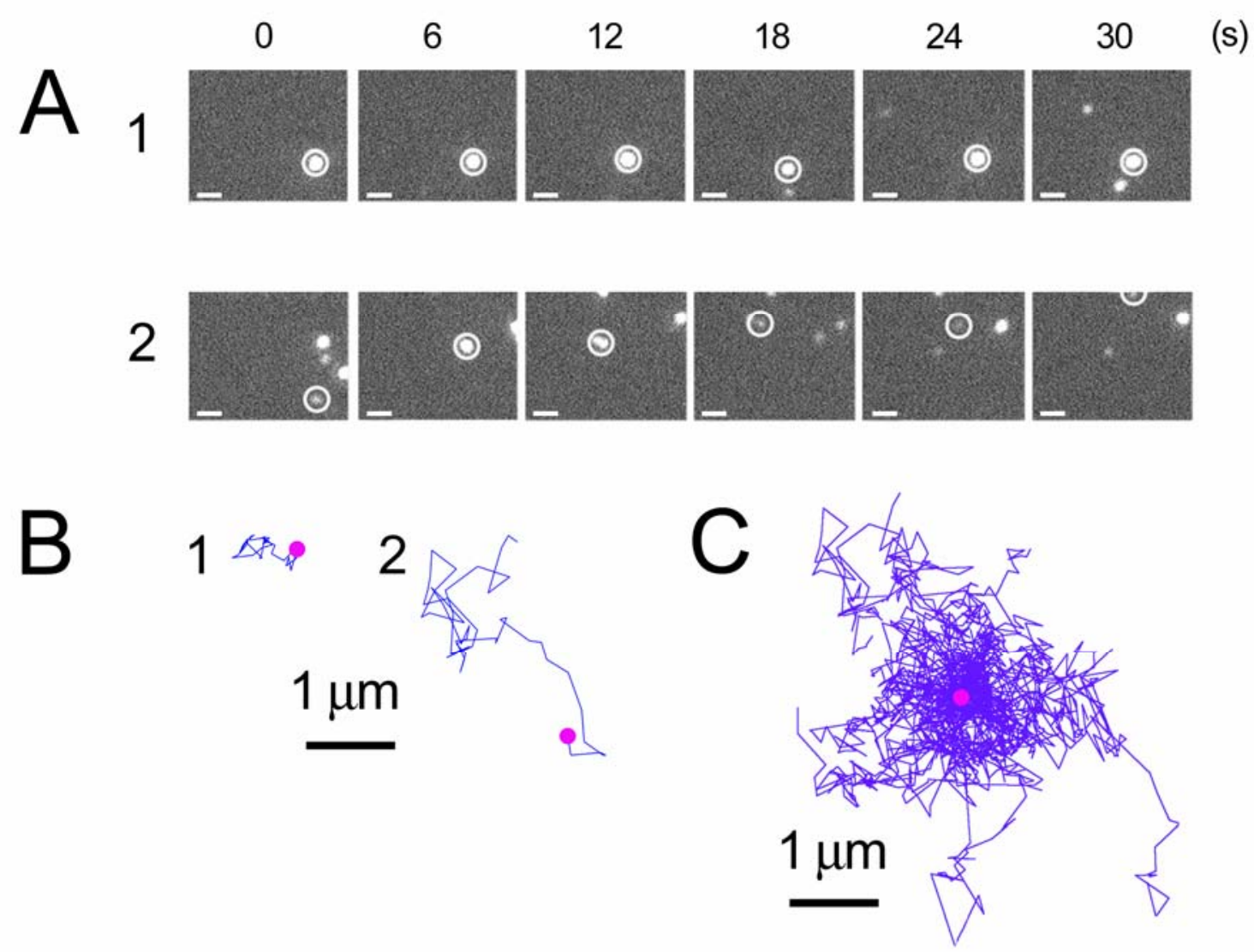

Figure 3.5: Motion of single $\mathrm{hK}_{\mathrm{ca}} 3.1$ channels in the plasma membrane. (A). Frames from time-lapse TIRF microscopy imaging of single $\mathrm{hK}_{\mathrm{Ca}} 3.1$ channels. The selected $\mathrm{hK}_{\mathrm{Ca}} 3.1$ channels are marked with a circle and correspond to trajectories 1 and 2 in Fig.3.4C. The scale bars represent $1 \mu \mathrm{m}$. (B). Trajectories $(1,2)$ of two $\mathrm{hK}_{\mathrm{Ca}} 3.1$ channels in the plasma membrane of the cell. Channel movement was monitored for $30 \mathrm{~s}$. (See also movie 3 and movie 4 in supplemental material). Starting positions of the $\mathrm{hK}_{\mathrm{ca}} 3.1$ channels are marked as the magenda dots. (C). Trajectories of single QD-labeled $\mathrm{hK}_{\mathrm{Ca}} 3.1$ channels in the plasma membrane shifted to a common starting point from the same cell (Fig. 3.4C). 
The dynamics of QDs can be quantified by the time-dependent behavior of the mean squared displacement according to formula F1. Figure 3.6A shows the $m s d$ of all $N_{Q D}=534$ tracked $\mathrm{K}_{\mathrm{Ca}} 3.1$ channels. At first view, the double-logarithmic plot indicates a power-law scaling over the observed time range. However, at smaller times the msd displays a larger inclination. The application of formula F2 shows that this is an error produced by the finite observation time (shutter time $\eta=0.2 \mathrm{~s}$ ). In our case, the error of position measurement $\varepsilon \sim 0.03-0.04 \mu \mathrm{m}$ makes only a marginal contribution of $(2 \varepsilon)^{2} \sim 0.0036-0.0064 \mu \mathrm{m}^{2}$ to the $\mathrm{msd}$ (which has a value of $\sim 0.15$ $\mu \mathrm{m}^{2}$ at the smallest time $0.6 \mathrm{~s}$ ) and is thus negligible. Table 1 summarizes the numerical values of the parameters describing $\mathrm{K}_{\mathrm{C} a} 3.1$ dynamics that were obtained with Bayesian data analysis. The diffusion coefficient $D_{\alpha}$ is the same for all regions of the cell: $D_{\alpha}=0.067 \mu \mathrm{m}^{2} / \mathrm{s}^{\alpha}$. Interestingly, the coefficient $\alpha$ that classifies the mode of diffusion is smaller than 1 . The average value for all $\mathrm{hK}_{\mathrm{Ca}} 3.1$ channels studied is $\alpha$ $=0.82$. Interestingly, the mean squared displacement of the $\mathrm{hK}_{\mathrm{Ca}} 3.1$ channel proteins varies depending on the localization within the cell (Fig. 3.6B). $h K_{\mathrm{ca}} 3.1$ channels move farthest in the plasma membrane of the cell body while they cover smaller distances at the uropod. This can be explained by differences in the subdiffusion coefficient $\alpha$ (Fig. 3.7). It reaches its highest value $(\alpha=0.87)$ at the cell body, while it is lowest at the uropod $(\alpha=0.74)$. Channels at the leading edge and within the lamellipodium exhibit an intermediate value of $\alpha$. Taken together these results clearly indicate that diffusion of $\mathrm{hK}_{\mathrm{Ca}} 3.1$ channels in the plasma membrane of MDCK-F cells is a subdiffusive process. It is most subdiffusive at the uropod. 


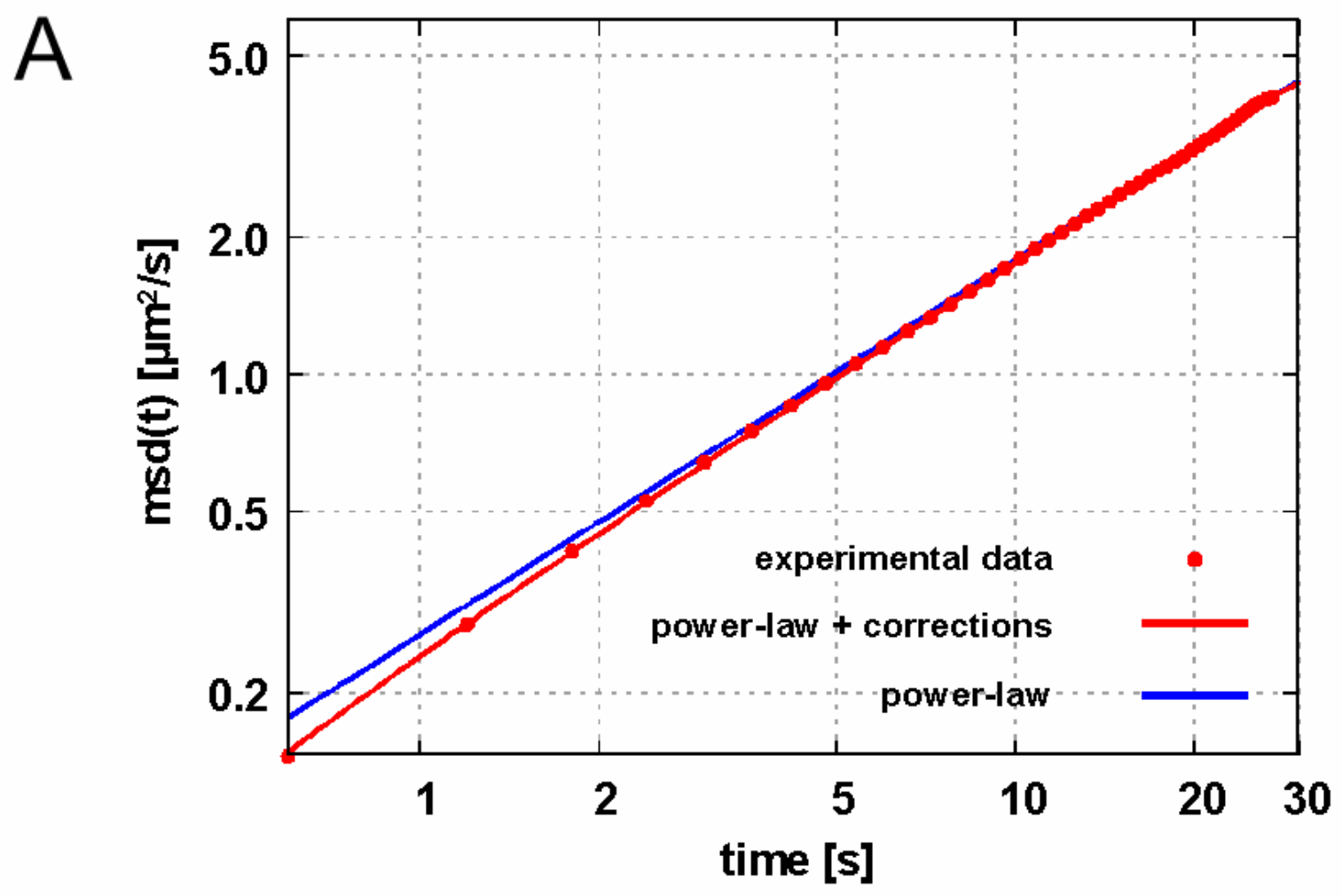

B

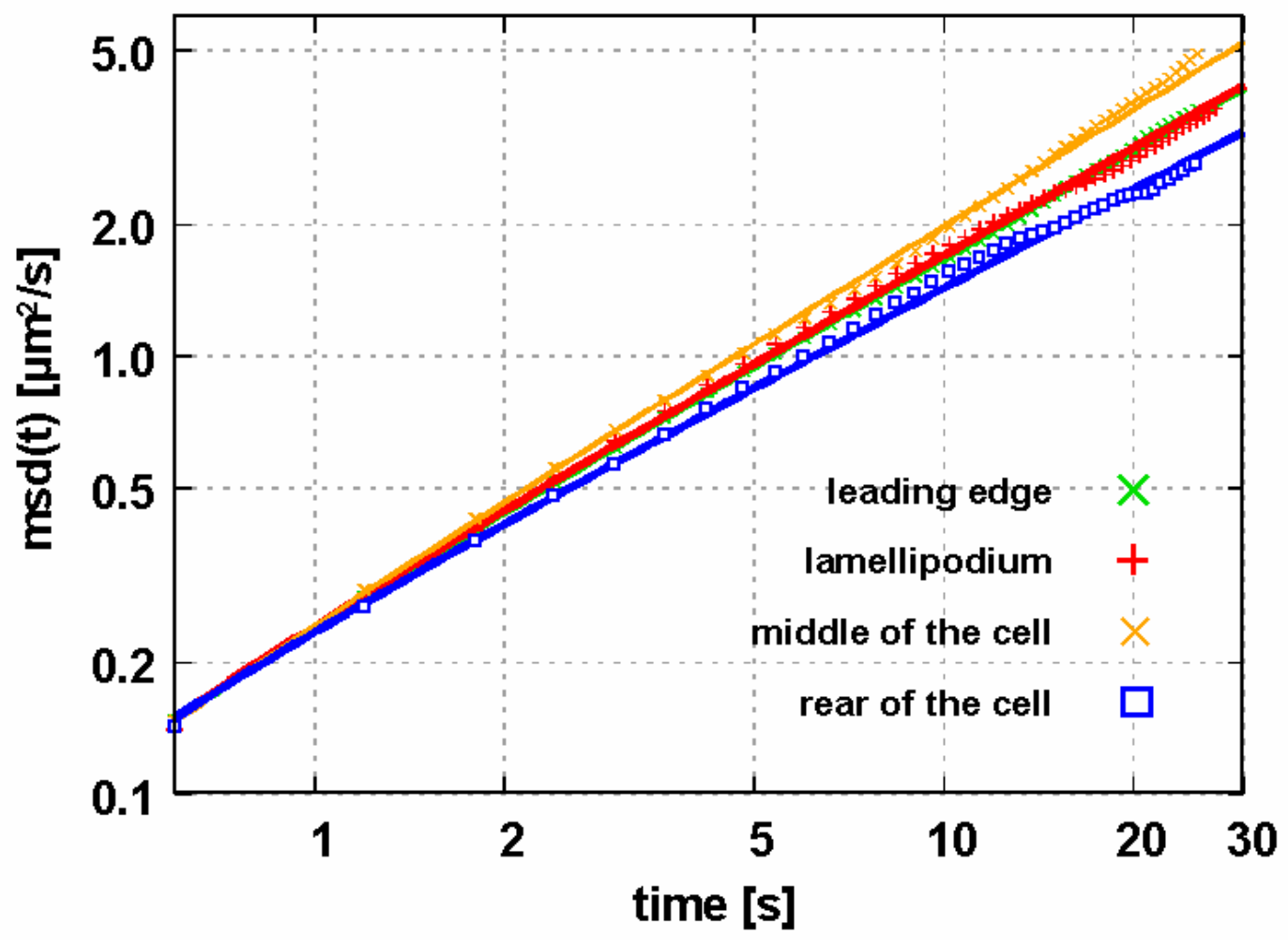

Figure 3.6: Mean-squared displacement (msd) of the QD labeled $\mathrm{hK}_{\mathrm{ca}} 3.1$ channels in the plasma membrane of migrating MDCK-F cells. Symbols indicate the results of the experimental measurements of the $m s d$ in different regions of the cell. Continuous curves represent the result of fitting the msd-data to a power-law model (see methods). (A) The msd of all observed QDs is in good agreement with the power-law scaling and the corrections of (Savin and Doyle, 2005). The blue curve shows the pure power-law without corrections which cannot describe the transition at smaller times. (B) The msd is resolved for the four different cell regions. It displays a similar subdiffusive behavior in all four regions (for details see table 1). (Nechyporuk-Zloy et al., submitted) 


\section{Table 1}

Results of a data fit of the experimental data with the model of Savin and Doyle (Savin and Doyle, 2005) according to formula F3. The shutter time $\eta=0.20 \pm 0.02 \mathrm{~s}$ was implemented in form of a Gaussian prior into the parameter estimation.

\begin{tabular}{|c|c|c|c|}
\hline region & $\mathrm{N}$ & $\mathrm{D}_{\alpha}\left[\mu \mathrm{m}^{2} / \mathrm{s}^{\alpha}\right]$ & $\alpha$ \\
\hline all & 534 & $0.067 \pm 0.0005$ & $0.82 \pm 0.003$ \\
\hline leading edge & 153 & $0.067 \pm 0.001$ & $0.81 \pm 0.01$ \\
\hline lamellipodium & 162 & $0.068 \pm 0.001$ & $0.81 \pm 0.01$ \\
\hline cell body & 155 & $0.067 \pm 0.001$ & $0.88 \pm 0.01$ \\
\hline uropod & 64 & $0.068 \pm 0.001$ & $0.74 \pm 0.01$ \\
\hline
\end{tabular}




\section{Subdiffusion Exponent, $\alpha$}

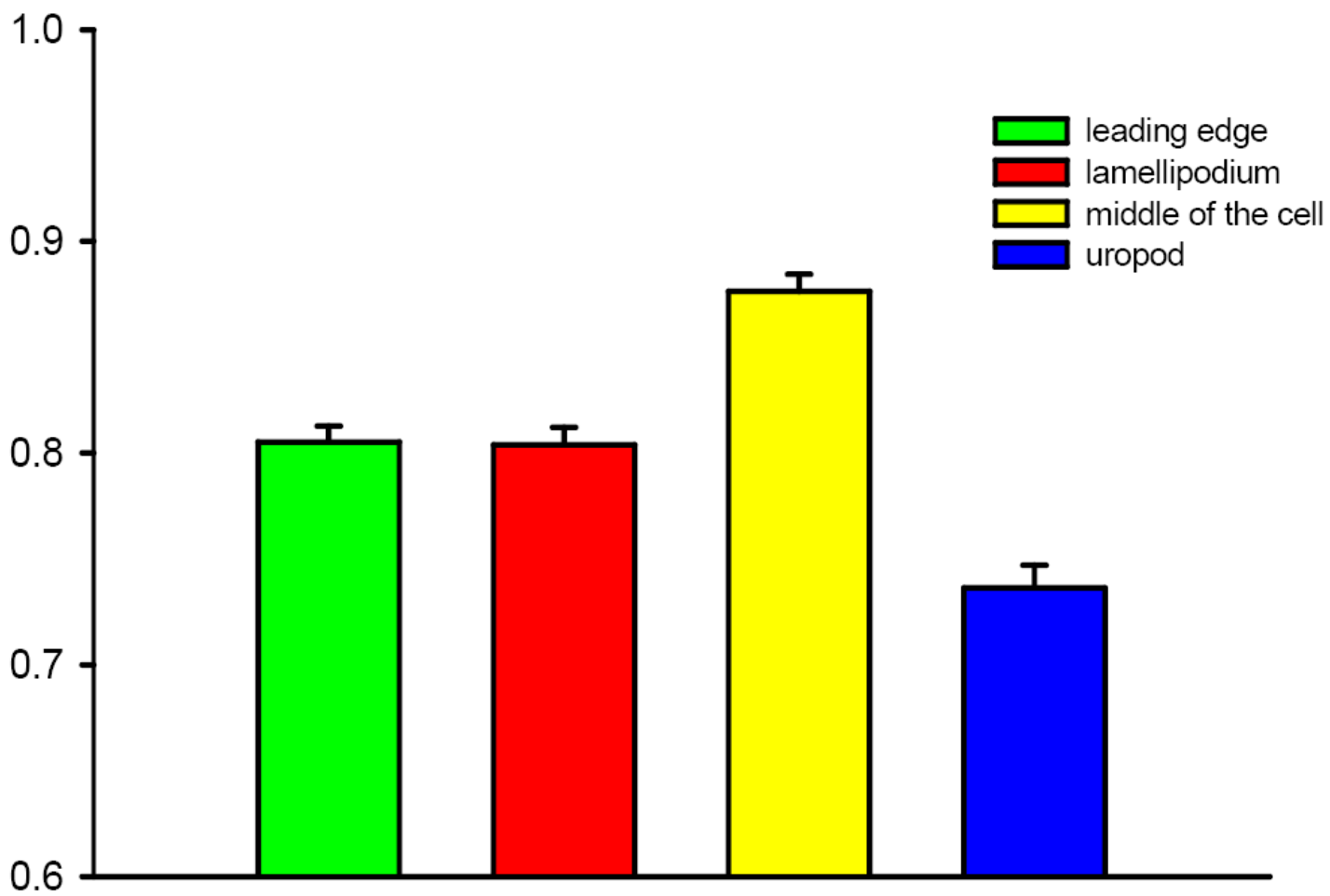

Figure 3.7: Summary of the subdiffusion coefficients $\alpha$ in different regions of the cell. Their value is smaller than 1 throughout the cell pointing to the subdiffusive nature of $\mathrm{hK}_{\mathrm{Ca}} 3.1$ channel dynamics (see also table 1). 
To characterise completely the dynamics of $\mathrm{K}_{\mathrm{Ca}} 3.1$ channels we need to calculate probability distribution function (PDF) of ion channel position in the plasma membrane versus time (Supplemental Material Fig. 2). PDF assigns the probability that the ion channel coordinate will take a value in a distinct interval. Unfortunately, the values of PDF are changed due to finite shutter time and to further classify the nature of the dynamic process, we calculated the kurtosis of the mobile $\mathrm{K}_{\mathrm{Ca}} 3.1$ channels according to equation (F4). Figure 3.8 displays the kurtosis of the $\mathrm{K}_{\mathrm{Ca}} 3.1$ channels as function of time. The kurtosis is saturated at a value of slightly above 4 and thereby indicates the anomalous (non-Gaussian) dynamics of $\mathrm{hK}_{\mathrm{Ca}} 3.1$ channel movement. It shows also that the channel protein has high probability to be near the starting point or far away in comparison to normal diffusion during observation (Supplemental Material Fig. 2). However, the initial decrease of the kurtosis seems to be an artefact of the relatively long shutter time. The magenta curve was calculated for a normal diffusive random walk whose one-dimensional forth moment is given by $12 D t^{4}$ and corrected in order to account for the finite shutter time (Savin and Doyle, 2005). The simulated curve also shows the artificial decrease converging towards a value of 3 for larger times.

Finally, the movement of $\mathrm{K}_{\mathrm{Ca}} 3.1$ channels was analyzed separately for each cell in order to test whether it follows a drift that may be generated by the movement of the cell or by directed transport processes of the channel proteins itself (Supplemental Material Table 1). The estimated error of $v_{\text {drift }}$ was always larger than the corresponding mean value. In addition, simulation of random walk processes with similar parameters as those obtained for $\mathrm{K}_{\mathrm{Ca}} 3.1$ channels from our experiments for $\mathrm{a}$ variety of drift values showed, that $v_{\text {drift }}$ had to be larger than about $0.1 \mu \mathrm{m} / \mathrm{s}$ in order to be detected with certainty (Fig. 3.9). 


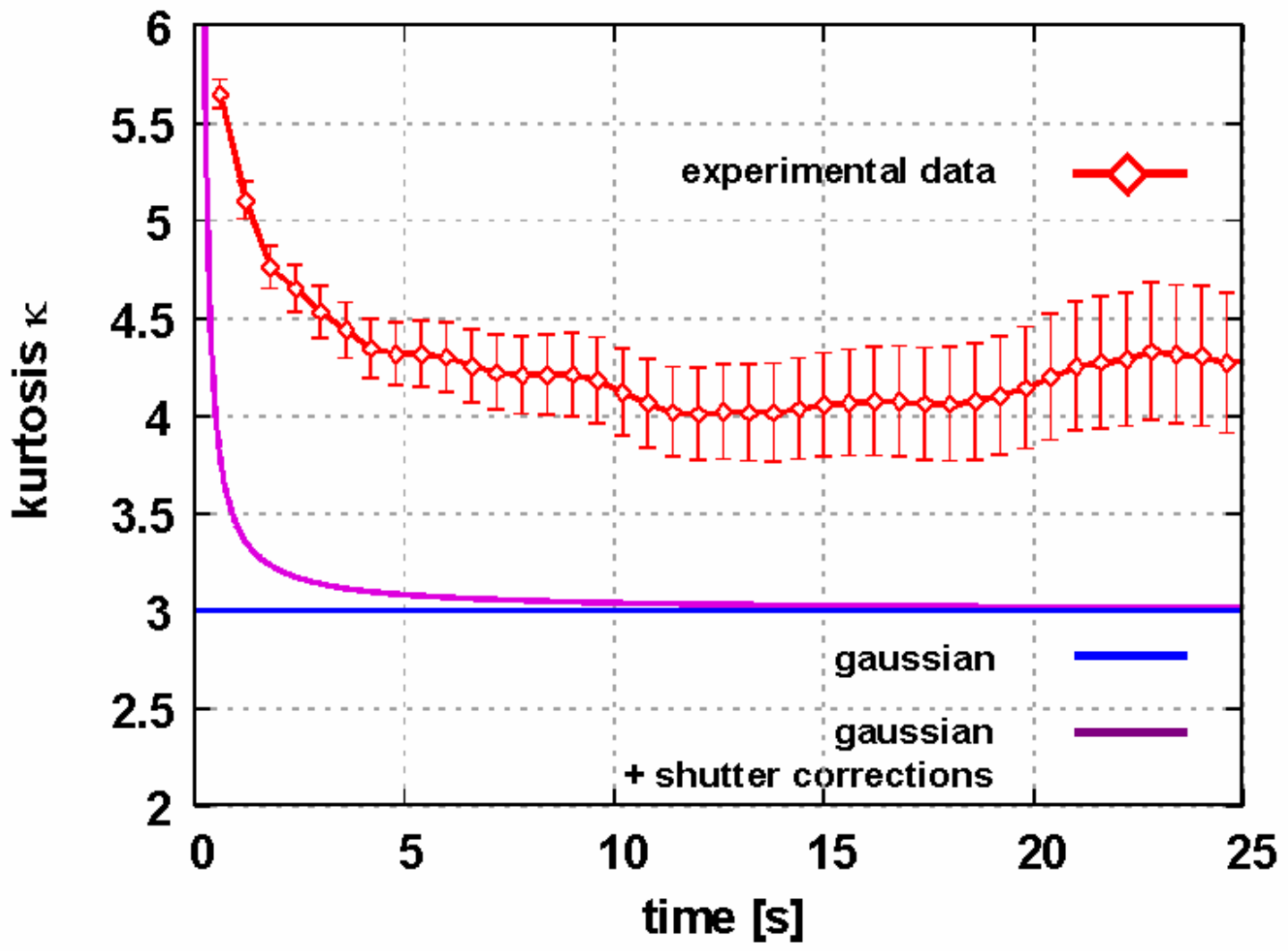

Figure 3.8: Kurtosis as function of time. The experimental data show an initial increase saturating slightly above a value of 4 for larger times. The data are compared to a normal diffusive (gaussian) process displaying a kurtosis of 3 (blue curve). The magenta curve describes the influence of the finite shutter time for the normal diffusive process which generates an artificial transition at small times to the theoretical value of 3 at later times. (Nechyporuk-Zloy et al., submitted) 


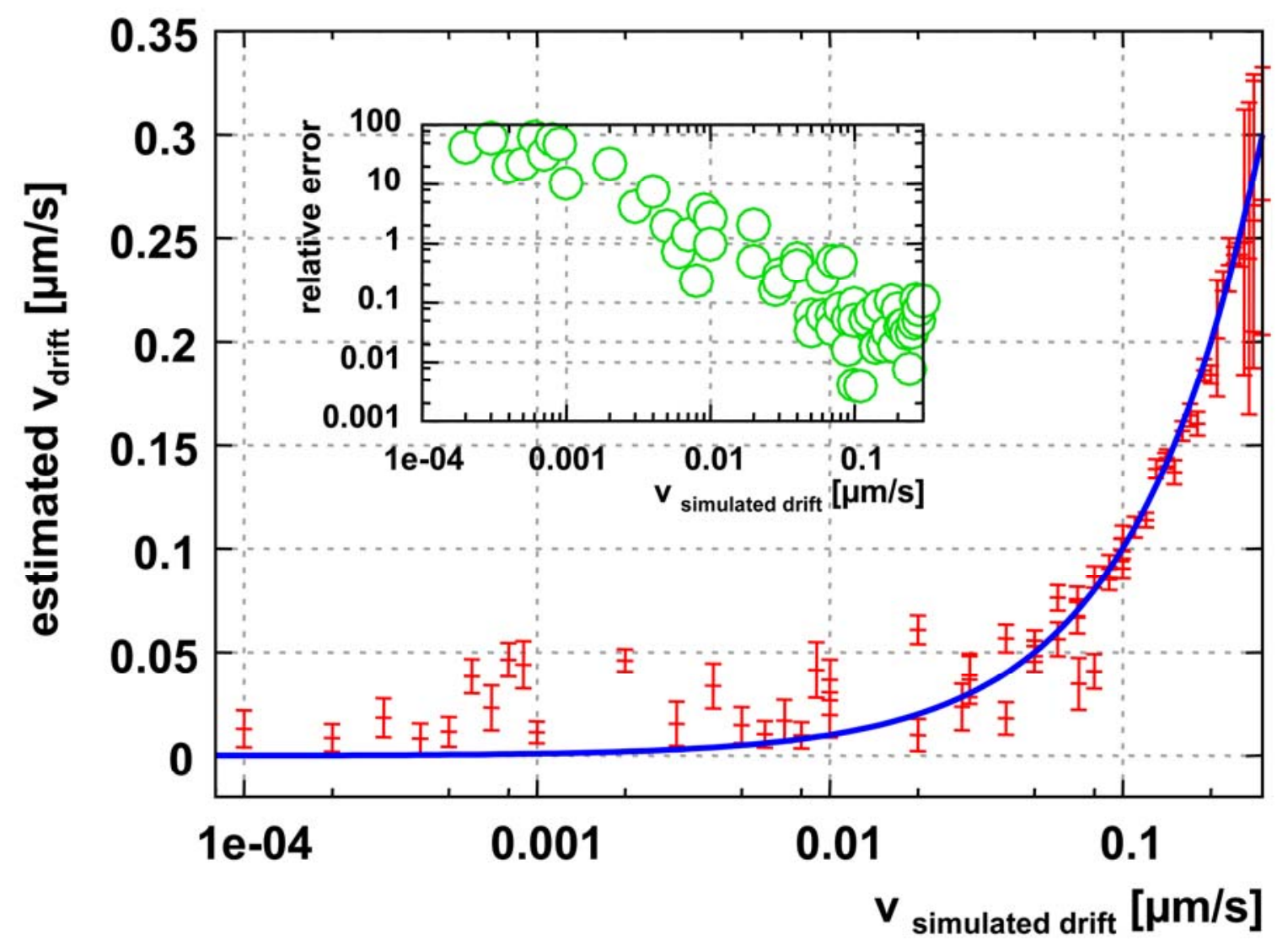

Figure 3.9: Estimation of ion channel drift and relative error. The red bars show the estimated value of $v_{\text {drift }}$ for different simulations (with different $v_{\text {simulated drift }}$ ). The magenta curve describes the average value of estimated $v_{\text {drift. }}$. Corresponding values of relative error are shown as green circles. 


\section{Discussion}

\subsection{Single Molecule Detection of Potassium Channel}

Each $\mathrm{hK}_{\mathrm{Ca}} 3.1$ channel protein is a tetramer, meaning that it has four binding sites for antibodies and QDs that can be completely or partially occupied. Assuming the equal binding of four QDs to the potassium channel the relative frequencies of red and green QDs should behave as predicted by a binomial distribution: $(a+b)^{4}=a^{4}+4 a^{3} b+6 a^{2} b^{2}+4 a b^{3}+b^{4}$. I derived $a=0.45$ and $b=0.50$ from our experiments (Fig. 3.10). $a^{4}$ and $b^{4}$ are the probabilities that four green or four red QDs bind to the channel, respectively. $4 a^{3} b+6 a^{2} b^{2}+4 a b^{3}$ is the probability that different combinations of one, two, or three green and red QDs bind simultaneously. We can then calculate that almost $90 \%$ of the channels should be labeled by green and red QDs simultaneously and therefore appear "yellow". This is in clear contrast to our experimental findings. I therefore modified our model calculation to the binding of only two QDs per channel protein: $(a+b)^{2}=a^{2}+2 a b+b^{2}$. $a^{2}$ and $b^{2}$ are the probabilities that two green or two red QDs bind to the channel, and 2ab is the probability that one green and one red QD bind to the channel at the same time ("yellow"). We can then calculate that $45 \%$ of the channels should be labeled by one green and one red QD and therefore appear "yellow" which is also in contradiction to our experimental results. We therefore conclude that both models are not valid. In our view the easiest explanation to account for this apparent discrepancy is to assume that most potassium channel molecules are labeled by only one QD.

If channels can be dually labeled by red and green QDs they can also bind either two (or more) red or two (or more) green QDs, respectively. The technique does not allow to distinguish between binding of one or of multiple QDs of the same colour. Thus, we must assume that in addition to $3.3 \%$ dually labeled "yellow" hK $\mathrm{Ca}_{\mathrm{Ca}} 3.1$ channels we also labeled $3.3 \%$ with more than one red or green QD, respectively. Nonetheless, $93.4 \%$ of the QDs observed are single and labeled single potassium channel molecules.

Potassium channel proteins have a diameter of approximately $10 \mathrm{~nm}$ (Jiang et al., 2002; Sokolova et al., 2001). Antibodies have a size of $8 \mathrm{~nm}$ (Hartmann et al., 2004), and according to the manufacturer the diameter of the QDs used in our study is 10 
$\mathrm{nm}$. Thus, the maximal distance between the optical centers of two QD's bound to a single channel protein is in the order of $50 \mathrm{~nm}$ (Fig. 4.1). This corresponds to a distance of 1 pixel in the digitized image. Therefore, two QDs with a distance between optical centers of more than two pixels must be placed on two different potassium channel proteins. The geometric model (Fig. 4.1) in combination with the crystal structure of the voltage-gated Kv1.2 potassium channel (Long et al., $2005 b$;Long et al., 2005c) may also provide an explanation for the fact that the vast majority of $\mathrm{hK}_{\mathrm{Ca}} 3.1$ channel proteins is labeled by only one QD. Voltage-gated potassium channels when viewed from the extracellular side resemble a four-leaf clover. S3-S4 linkers are in the "leaves" so that they are less than $10 \mathrm{~nm}$ apart from each other. Assuming a similar structure for calcium-activated $\mathrm{hK}_{\mathrm{Ca}} 3.1$ channels they also have six transmembrane spanning domains - one can hypothesize that steric hindrance prevents the binding of more than one QD-labeled antibody to the HA-tag in the S3-S4 linker.

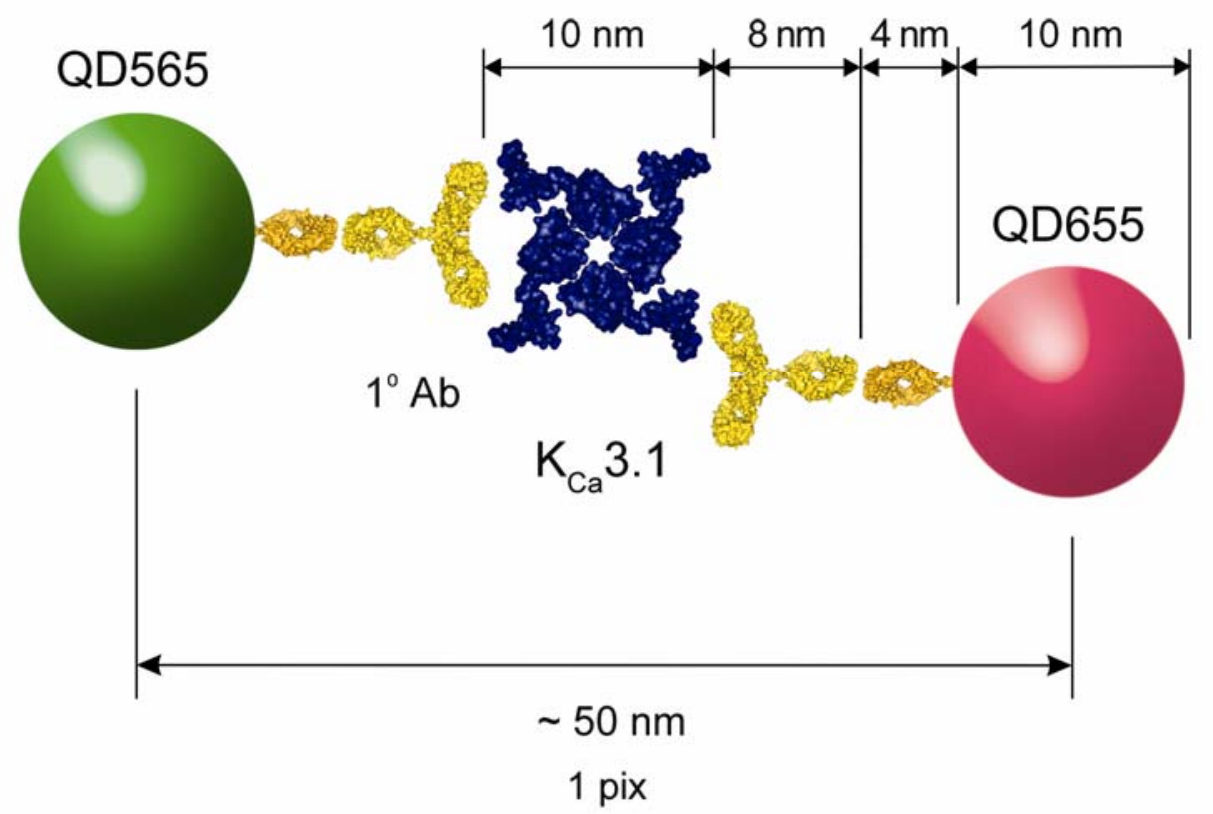

Figure 4.1: Geometric model of $\mathrm{QD}$ binding to a $\mathrm{hK}_{\mathrm{Ca}} 3.1$ channel protein. The potassium channel structure which is adopted from a voltage-gated potassium channel (4) somewhat resembles a four-leaf clover. The S3-S4 linker containing the HA-tag is situated in the "leaves". The maximal distance of the optical centers of two QDs amounts to approximately $50 \mathrm{~nm}$. I used atomic coordinates of Kv1.2 (Protein Data Bank ID 2A79; (Long et al., 2005a)) and atomic coordinates of the model of an entire human IgG1 molecule (Padlan, 1994) for generation of the figure with PyMOL software (DeLano Scientific, San Carlos, CA, USA). ( $1^{\circ} \mathrm{Ab}$ : primary antibody, $2^{\circ} \mathrm{Ab}$ : secondary antibody). (Nechyporuk-Zloy et al., 2006) 
In summary I described a simple method for the detection of potassium channels on the single molecule level. I anticipate that this method can be adopted to other ion channels as well. Moreover, by combining intra- and extracellular tags inserted to different subunits this method may also be used for identifying the subunit composition of hetero-oligomeric ion channels. Subsequent, separate labeling of an extracellular domain of subunit A prior to permeabilization and an intracellular domain of subunit B after permeabilization with differently coloured QDs should facilitate the stoichiometry analysis of the channels' subunit composition. Total internal reflection fluorescence microscopy would provide the 10-nm resolution (Churchman et al., 2005) needed for the spatial segregation of the two different dyes.

\subsection{Motion of $\mathrm{K}_{\mathrm{ca}}$ 3.1 Channel Protein in the Plasma Membrane is Subdiffusive} Previous studies on the mobility of ion channel proteins gave different values of mean diffusion coefficients: $0.0002 \mu \mathrm{m}^{2} / \mathrm{s}\left(\mathrm{K}_{\mathrm{V}} 1.3\right)$ (Schütz et al., 2000), $0.02 \mu \mathrm{m}^{2} / \mathrm{s}$ (Kv2.1) (O'Connell et al., 2006), $0.005 \mu \mathrm{m}^{2} / \mathrm{s}$ (CFTR) (Haggie et al., 2006), $0.1 \mu \mathrm{m}^{2} / \mathrm{s}$ (Glycine receptor) (Dahan et al., 2003) $0.15 \pm 0.05 \mu \mathrm{m}^{2} / \mathrm{s}$ (L-type $\mathrm{Ca}^{2+}$ channels) (Harms et al., 2001). Based on these values ion channels can apparently be divided into two groups: channels that are vitally immobile and channels that are mobile in the plasma membrane. $\mathrm{K}_{\mathrm{Ca}} 3.1$ channels investigated in the present study clearly belong to the second group of mobile ion channels. Their diffusion coefficient is of the same order of magnitude as that of L-type $\mathrm{Ca}^{2+}$ channels or glycine receptors. The cellular context in which ion channels are studied appears to play an important role with respect to their mobility. $\mathrm{K}_{\mathrm{V}} 1.3$ channels are stationary in lymphocytes (Jurkat cells), however they are highly mobile when expressed in HEK293 cells. On the other hand $\mathrm{K}_{\mathrm{V}} 1.2$ channels are relatively immobile in their native environment (hippocampus neurons) and in HEK293 cells. The immobility of ion channels was explained with clustering by binding to the actin cytoskeleton. Thus, disrupting the C-terminally mediated binding to the actin cytoskeleton largely increased the mobility of CFTR molecules in the plasma membrane (Haggie et al., 2006).

My study suggests that $\mathrm{K}_{\mathrm{Ca}} 3.1$ channels are apparently not as tightly tethered to the actin cytoskeleton like CFTR molecules. Nevertheless, it is noteworthy that diffusion 
of $\mathrm{K}_{\mathrm{Ca}} 3.1$ channels in migrating MDCK-F cells occurs in a subdiffusive manner. This is the case for all cell regions including the leading edge. These findings suggest that the concentration of $\mathrm{K}_{\mathrm{Ca}} 3.1$ channels at the leading edge of migrating cells (Schwab et al., 2006) is not due to a restricted mobility of the channel proteins at this cell pole. So far I do not know why diffusion of $\mathrm{K}_{\mathrm{Ca}} 3.1$ channels is a subdiffusive process. The time resolution of our experiment does not allow to detect "hop diffusion" across "fences" or around "pickets" in the plasma membrane (Kusumi et al., 2005). An alternative explanation for subdiffusion of $\mathrm{K}_{\mathrm{Ca}} 3.1$ channels could be their association with lipid rafts (Barfod et al., 2007). I dismiss the possibility that the subdiffusive behavior of $\mathrm{K}_{\mathrm{Ca}} 3.1$ channels is a technical artefact due to QD labeling at the "basal" plasma membrane of MDCK-F cells. $\mathrm{K}_{\mathrm{Ca}} 3.1$ channels are labeled evenly at the entire cell membrane and the movement of unbound QDs is much faster than the movement of $\mathrm{K}_{\mathrm{Ca}} 3.1$ channels. Motion of unbound QDs can be estimated by assuming free thermal diffusion and a Stokes-Einstein relation (Hansen and McDonald, 1990). The coefficient of unbound QDs is expected to be two orders of magnitude larger than our experimental results indicating that the motion is mainly determined by the coupled channel dynamics The diffusion coefficient of unbound QDs can be calculated according to the following formula $D_{t h}=k_{B} T /\left(6 \pi \eta_{\text {med }} r\right)$. With the Boltzmann constant $k_{B}$, the temperature of the experiment $T=37^{\circ} \mathrm{C}$, the radius of the quantum dot $r \sim 5 \mathrm{~nm}$, and the viscosity of the medium $\eta_{\text {med }}$. Assuming the viscosity of medium to be 10 times that of water $h_{\text {water }} \sim 7.0 \cdot 10^{-4} \mathrm{~Pa} \cdot \mathrm{s}$ (tacking into account the influence of serum) a thermal diffusion coefficient $D_{\text {thermal }} \sim 6.5 \mu \mathrm{m}^{2} / \mathrm{s}$ is obtained.

My finding that dynamics of $\mathrm{K}_{\mathrm{Ca}} 3.1$ channels are not superimposed by the drift is consistent with earlier studies in which single particle tracing failed to detect a directed flow of membrane lipid in motile cells (Kucik et al., 1990; Lee et al., 1990; Sheetz et al., 1989). 


\section{References}

1. Alberts, B., A.Johnson, J.Lewis, M.Raff, K.Roberts, and P.Walter. 2002. Molecular biology of the cell. Garland Science, New York.

2. Alivisatos AP. 1996. Semiconductor clusters, nanocrystals, and quantum dots. Science 271:933-937.

3. Barfod, E.T., A.L.Moore, M.W.Roe, and S.D.Lidofsky. 2007. Ca2+-activated IK1 channels associate with lipid rafts upon cell swelling and mediate volume recovery. J. Biol Chem.

4. Blanchoin, L., K.J.Amann, H.N.Higgs, J.B.Marchand, D.A.Kaiser, and T.D.Pollard. 2000. Direct observation of dendritic actin filament networks nucleated by Arp2/3 complex and WASP/Scar proteins. Nature 404:10071011.

5. Borisy, G.G. and T.M.Svitkina. 2000. Actin machinery: pushing the envelope. Curr. Opin. Cell Biol. 12:104-112.

6. Bray, D. 2001. Cell movements: from molecules to motility.

7. Bretscher, M.S. 1984. Endocytosis: relation to capping and cell locomotion. Science 224:681-686.

8. Bretscher, M.S. 1996. Getting membrane flow and the cytoskeleton to cooperate in moving cells. Cell 87:601-606.

9. Bruchez, M., Jr., M.Moronne, P.Gin, S.Weiss, and A.P.Alivisatos. 1998. Semiconductor nanocrystals as fluorescent biological labels. Science 281:2013-2016.

10. Chan, W.C. and S.Nie. 1998. Quantum dot bioconjugates for ultrasensitive nonisotopic detection. Science 281:2016-2018. 
11. Churchman, L.S., Z.Okten, R.S.Rock, J.F.Dawson, and J.A.Spudich. 2005. Single molecule high-resolution colocalization of Cy3 and Cy5 attached to macromolecules measures intramolecular distances through time. Proc. Natl. Acad. Sci. U. S. A 102:1419-1423.

12. Cramer, L.P. 1999. Organization and polarity of actin filament networks in cells: implications for the mechanism of myosin-based cell motility. Biochem. Soc. Symp. 65:173-205.

13. Cramer, L.P., M.Siebert, and T.J.Mitchison. 1997. Identification of novel graded polarity actin filament bundles in locomoting heart fibroblasts: implications for the generation of motile force. J. Cell Biol. 136:1287-1305.

14. Dahan, M., S.Levi, C.Luccardini, P.Rostaing, B.Riveau, and A.Triller. 2003. Diffusion dynamics of glycine receptors revealed by single-quantum dot tracking. Science 302:442-445.

15. Denker, S.P. and D.L.Barber. 2002. Cell migration requires both ion translocation and cytoskeletal anchoring by the $\mathrm{Na}-\mathrm{H}$ exchanger NHE1. J. Cell Biol 159:1087-1096.

16. Denker, S.P., D.C.Huang, J.Orlowski, H.Furthmayr, and D.L.Barber. 2000. Direct binding of the Na--H exchanger NHE1 to ERM proteins regulates the cortical cytoskeleton and cell shape independently of $\mathrm{H}^{+}$translocation. $\mathrm{Mol}$ Cell 6:1425-1436.

17. Eder, C. 1998. Ion channels in microglia (brain macrophages). Am. J. Physiol 275:C327-C342.

18. Etienne-Manneville, S. 2004. Actin and microtubules in cell motility: which one is in control? Traffic. 5:470-477.

19. Fabbri, M., L.Fumagalli, G.Bossi, E.Bianchi, J.R.Bender, and R.Pardi. 1999. A tyrosine-based sorting signal in the beta2 integrin cytoplasmic domain 
mediates its recycling to the plasma membrane and is required for ligandsupported migration. EMBO J. 18:4915-4925.

20. Garini, Y., B.J.Vermolen, and I.T.Young. 2005. From micro to nano: recent advances in high-resolution microscopy. Curr. Opin. Biotechnol. 16:3-12.

21. Gordon, M.P., T.Ha, and P.R.Selvin. 2004. Single-molecule high-resolution imaging with photobleaching. Proc. Natl. Acad. Sci. U. S. A 101:6462-6465.

22. Grinstein, S., M.Woodside, T.K.Waddell, G.P.Downey, J.Orlowski, J.Pouyssegur, D.C.Wong, and J.K.Foskett. 1993. Focal localization of the $\mathrm{NHE}-1$ isoform of the $\mathrm{Na}^{+} / \mathrm{H}^{+}$antiport: assessment of effects on intracellular pH. EMBO J. 12:5209-5218.

23. Haggie, P.M., J.K.Kim, G.L.Lukacs, and A.S.Verkman. 2006. Tracking of quantum dot-labeled CFTR shows near immobilization by C-terminal PDZ interactions. Mol. Biol. Cell 17:4937-4945.

24. Hansen, J.P. and I.R.McDonald. 1990. Theory of Simple Liquids. Elsevier Academic Press, London.

25. Harms, G.S., L.Cognet, P.H.Lommerse, G.A.Blab, H.Kahr, R.Gamsjager, H.P.Spaink, N.M.Soldatov, C.Romanin, and T.Schmidt. 2001. Singlemolecule imaging of I-type $\mathrm{Ca}^{2+}$ channels in live cells. Biophys. J. 81:26392646.

26. Hartmann, W.K., N.Saptharishi, X.Y.Yang, G.Mitra, and G.Soman. 2004. Characterization and analysis of thermal denaturation of antibodies by size exclusion high-performance liquid chromatography with quadruple detection. Anal. Biochem. 325:227-239.

27. Ishii, T.M., C.Silvia, B.Hirschberg, C.T.Bond, J.P.Adelman, and J.Maylie. 1997. A human intermediate conductance calcium-activated potassium channel. Proc. Natl. Acad. Sci. U. S. A 94:11651-11656. 
28. Jager, H., T.Dreker, A.Buck, K.Giehl, T.Gress, and S.Grissmer. 2004. Blockage of intermediate-conductance $\mathrm{Ca}^{2+}$-activated $\mathrm{K}^{+}$channels inhibit human pancreatic cancer cell growth in vitro. Mol. Pharmacol. 65:630-638.

29. Jaynes, E.T. 2003. Probability Theory: The Logic of Science. Cambridge University Press, Cambridge.

30. Jiang, Y., A.Lee, J.Chen, M.Cadene, B.T.Chait, and R.MacKinnon. 2002. The open pore conformation of potassium channels. Nature 417:523-526.

31. Jin, M., D.M.Defoe, and R.Wondergem. 2003. Hepatocyte growth factor/scatter factor stimulates $\mathrm{Ca}^{2+}$-activated membrane $\mathrm{K}^{+}$current and migration of MDCK II cells. J. Membr. Biol. 191:77-86.

32. Kim, M.J., G.Cheng, and D.K.Agrawal. 2004. Cl- channels are expressed in human normal monocytes: a functional role in migration, adhesion and volume change. Clin. Exp. Immunol. 138:453-459.

33. Klein, M., P.Seeger, B.Schuricht, S.L.Alper, and A.Schwab. 2000.

Polarization of $\mathrm{Na}^{+} / \mathrm{H}^{+}$and $\mathrm{Cl}^{-} / \mathrm{HCO}^{3-}$ exchangers in migrating renal epithelial cells. J. Gen. Physiol 115:599-608.

34. Koch, S., K.Kohl, E.Klein, D.von Bubnoff, and T.Bieber. 2006. Skin homing of Langerhans cell precursors: adhesion, chemotaxis, and migration. J. Allergy Clin. Immunol. 117:163-168.

35. Kohler, R., H.Wulff, I.Eichler, M.Kneifel, D.Neumann, A.Knorr, I.Grgic, D.Kampfe, H.Si, J.Wibawa, R.Real, K.Borner, S.Brakemeier, H.D.Orzechowski, H.P.Reusch, M.Paul, K.G.Chandy, and J.Hoyer. 2003. Blockade of the intermediate-conductance calcium-activated potassium channel as a new therapeutic strategy for restenosis. Circulation 108:11191125. 
36. Kopfstein, L. and G.Christofori. 2006. Metastasis: cell-autonomous mechanisms versus contributions by the tumor microenvironment. Cell Mol. Life Sci. 63:449-468.

37. Kucik, D.F., E.L.Elson, and M.P.Sheetz. 1990. Cell migration does not produce membrane flow. J. Cell Biol 111:1617-1622.

38. Kusche, K., K.Sobczak, N.Bangel, V.Nechyporuk-Zloy, M.Wilhelmi, H.Schillers, A.Schwab, and H.Oberleithner. 2007. Aldosterone and amiloride modulate $\mathrm{ENaC}$ abundance in vascular endothelium. submitted.

39. Kusumi, A., C.Nakada, K.Ritchie, K.Murase, K.Suzuki, H.Murakoshi, R.S.Kasai, J.Kondo, and T.Fujiwara. 2005. Paradigm shift of the plasma membrane concept from the two-dimensional continuum fluid to the partitioned fluid: high-speed single-molecule tracking of membrane molecules. Annu. Rev. Biophys. Biomol. Struct. 34:351-378.

40. Lee, J., M.Gustafsson, K.E.Magnusson, and K.Jacobson. 1990. The direction of membrane lipid flow in locomoting polymorphonuclear leukocytes. Science 247:1229-1233.

41. Leibovitz, A. 1969. A transport medium for diagnostic virology. Proc. Soc. Exp. Biol. Med. 131:127-130.

42. Lidke, D.S., P.Nagy, R.Heintzmann, D.J.Arndt-Jovin, J.N.Post, H.E.Grecco, E.A.Jares-Erijman, and T.M.Jovin. 2004. Quantum dot ligands provide new insights into erbB/HER receptor-mediated signal transduction. Nat. Biotechnol. 22:198-203.

43. Long, S.B., E.B.Campbell, and R.MacKinnon. 2005a. Crystal structure of a mammalian voltage-dependent Shaker family $\mathrm{K}^{+}$channel. Science 309:897903. 
44. Long, S.B., E.B.Campbell, and R.MacKinnon. 2005b. Crystal structure of a mammalian voltage-dependent Shaker family $\mathrm{K}^{+}$channel. Science 309:897903.

45. Long, S.B., E.B.Campbell, and R.MacKinnon. 2005c. Voltage sensor of Kv1.2: structural basis of electromechanical coupling. Science 309:903-908.

46. Manahan, C.L., P.A.Iglesias, Y.Long, and P.N.Devreotes. 2004. Chemoattractant signaling in dictyostelium discoideum. Annu. Rev. Cell Dev. Biol. 20:223-253.

47. Marguet, D., P.F.Lenne, H.Rigneault, and H.T.He. 2006. Dynamics in the plasma membrane: how to combine fluidity and order. EMBO J. 25:34463457.

48. Martin, P. and S.J.Leibovich. 2005. Inflammatory cells during wound repair: the good, the bad and the ugly. Trends Cell Biol. 15:599-607.

49. Meyer, R., R.Schonherr, O.Gavrilova-Ruch, W.Wohlrab, and S.H.Heinemann. 1999. Identification of ether a go-go and calcium-activated potassium channels in human melanoma cells. J. Membr. Biol. 171:107-115.

50. Michalet, X., F.F.Pinaud, L.A.Bentolila, J.M.Tsay, S.Doose, J.J.Li, G.Sundaresan, A.M.Wu, S.S.Gambhir, and S.Weiss. 2005. Quantum dots for live cells, in vivo imaging, and diagnostics. Science 307:538-544.

51. Mogilner, A. and G.Oster. 1996. Cell motility driven by actin polymerization. Biophys. J. 71:3030-3045.

52. Moreland, J.G., A.P.Davis, G.Bailey, W.M.Nauseef, and F.S.Lamb. 2006. Anion channels, including $\mathrm{ClC}^{-3}$, are required for normal neutrophil oxidative function, phagocytosis, and transendothelial migration. J. Biol. Chem. 281:12277-12288. 
53. Munevar, S., Y.L.Wang, and M.Dembo. 2004. Regulation of mechanical interactions between fibroblasts and the substratum by stretch-activated $\mathrm{Ca}^{2+}$ entry. J. Cell Sci. 117:85-92.

54. Nechyporuk-Zloy, V., P.Dieterich, H.Oberleithner, C.Stock, and A.Schwab. 2007. Dynamics of single potassium channel proteins in the plasma membrane of migrating cells. submitted.

55. Nechyporuk-Zloy, V., C.Stock, H.Schillers, H.Oberleithner, and A.Schwab. 2006. Single plasma membrane $\mathrm{K}^{+}$channel detection by using dual-color quantum dot labeling. Am. J. Physiol Cell Physiol 291:C266-C269.

56. O'Connell, K.M., A.S.Rolig, J.D.Whitesell, and M.M.Tamkun. 2006. $\mathrm{K}_{\mathrm{v}} 2.1$ potassium channels are retained within dynamic cell surface microdomains that are defined by a perimeter fence. J. Neurosci. 26:9609-9618.

57. Ouadid-Ahidouch, H., M.Roudbaraki, P.Delcourt, A.Ahidouch, N.Joury, and N.Prevarskaya. 2004. Functional and molecular identification of intermediateconductance $\mathrm{Ca}^{2+}$-activated $\mathrm{K}^{+}$channels in breast cancer cells: association with cell cycle progression. Am. J. Physiol Cell Physiol 287:C125-C134.

58. Padlan, E.A. 1994. Anatomy of the antibody molecule. Mol. Immunol. 31:169217.

59. Parihar, A.S., M.J.Coghlan, M.Gopalakrishnan, and C.C.Shieh. 2003. Effects of intermediate-conductance $\mathrm{Ca}^{2+}$-activated $\mathrm{K}^{+}$channel modulators on human prostate cancer cell proliferation. Eur. J. Pharmacol. 471:157-164.

60. Pollard, T.D. and G.G.Borisy. 2003. Cellular motility driven by assembly and disassembly of actin filaments. Cell 112:453-465.

61. Reinhardt, J., N.Golenhofen, O.Pongs, H.Oberleithner, and A.Schwab. 1998. Migrating transformed MDCK cells are able to structurally polarize a voltageactivated $\mathrm{K}^{+}$channel. Proc. Natl. Acad. Sci. U. S. A 95:5378-5382. 
62. Ridley, A.J., M.A.Schwartz, K.Burridge, R.A.Firtel, M.H.Ginsberg, G.Borisy, J.T.Parsons, and A.R.Horwitz. 2003. Cell migration: integrating signals from front to back. Science 302:1704-1709.

63. Rodriguez, O.C., A.W.Schaefer, C.A.Mandato, P.Forscher, W.M.Bement, and C.M.Waterman-Storer. 2003. Conserved microtubule-actin interactions in cell movement and morphogenesis. Nat. Cell Biol. 5:599-609.

64. Sage, D., F.R.Neumann, F.Hediger, S.M.Gasser, and M.Unser. 2005. Automatic tracking of individual fluorescence particles: application to the study of chromosome dynamics. IEEE Trans. Image Process 14:1372-1383.

65. Savin, T. and P.S.Doyle. 2005. Static and dynamic errors in particle tracking microrheology. Biophys. J. 88:623-638.

66. Saxton, M.J. 1997. Single-particle tracking: the distribution of diffusion coefficients. Biophys. J. 72:1744-1753.

67. Saxton, M.J. and K.Jacobson. 1997. Single-particle tracking: applications to membrane dynamics. Annu. Rev. Biophys. Biomol. Struct. 26:373-399.

68. Schilling, T., C.Stock, A.Schwab, and C.Eder. 2004. Functional importance of $\mathrm{Ca}^{2+}$-activated $\mathrm{K}^{+}$channels for lysophosphatidic acid-induced microglial migration. Eur. J. Neurosci. 19:1469-1474.

69. Schneckenburger, H. 2005. Total internal reflection fluorescence microscopy: technical innovations and novel applications. Curr. Opin. Biotechnol. 16:1318.

70. Schneider, S.W., P.Pagel, C.Rotsch, T.Danker, H.Oberleithner, M.Radmacher, and A.Schwab. 2000. Volume dynamics in migrating epithelial cells measured with atomic force microscopy. Pflugers Arch. 439:297-303. 
71. Schütz, G.J., V.Ph.Pastushenko, H.J.Gruber, H.Knaus, B.Pragl, and H.Schindler. 2000. 3D imaging of individual ion channels in live cells at $40 \mathrm{~nm}$ resolution. Single $\mathrm{Mol}$ 1:25-31.

72. Schwab, A. 2001. Function and spatial distribution of ion channels and transporters in cell migration. Am. J. Physiol Renal Physiol 280:F739-F747.

73. Schwab, A., K.Gabriel, F.Finsterwalder, G.Folprecht, R.Greger, A.Kramer, and H.Oberleithner. 1995. Polarized ion transport during migration of transformed Madin-Darby canine kidney cells. Pflugers Arch. 430:802-807.

74. Schwab, A., V.Nechyporuk-Zloy, A.Fabian, and C.Stock. 2007. Cells move when ions and water flow. Pflugers Arch. 453:421-432.

75. Schwab, A., J.Reinhardt, S.W.Schneider, B.Gassner, and B.Schuricht. 1999a. $\mathrm{K}^{+}$channel-dependent migration of fibroblasts and human melanoma cells. Cell Physiol Biochem. 9:126-132.

76. Schwab, A., B.Schuricht, P.Seeger, J.Reinhardt, and P.C.Dartsch. 1999b. Migration of transformed renal epithelial cells is regulated by $\mathrm{K}^{+}$channel modulation of actin cytoskeleton and cell volume. Pflugers Arch. 438:330337.

77. Schwab, A., H.J.Westphale, L.Wojnowski, S.Wunsch, and H.Oberleithner. 1993. Spontaneously oscillating $\mathrm{K}^{+}$channel activity in transformed MadinDarby canine kidney cells. J. Clin. Invest 92:218-223.

78. Schwab, A., L.Wojnowski, K.Gabriel, and H.Oberleithner. 1994. Oscillating activity of a $\mathrm{Ca}^{2+}$-sensitive $\mathrm{K}^{+}$channel. A prerequisite for migration of transformed Madin-Darby canine kidney focus cells. J. Clin. Invest 93:16311636.

79. Schwab, A., A.Wulf, C.Schulz, W.Kessler, V.Nechyporuk-Zloy, M.Römer, J.Reinhardt, D.Weinhold, P.Dieterich, C.Stock, and S.C.Hebert. 2006. 
Subcellular distribution of calcium-sensitive potassium channels (IK1) in migrating cells. J. Cell Physiol 206:86-94.

80. Sheetz, M.P., S.Turney, H.Qian, and E.L.Elson. 1989. Nanometre-level analysis demonstrates that lipid flow does not drive membrane glycoprotein movements. Nature 340:284-288.

81. Sokolova, O., L.Kolmakova-Partensky, and N.Grigorieff. 2001. Threedimensional structure of a voltage-gated potassium channel at $2.5 \mathrm{~nm}$ resolution. Structure. 9:215-220.

82. Suzuki, K., K.Ritchie, E.Kajikawa, T.Fujiwara, and A.Kusumi. 2005. Rapid hop diffusion of a G-protein-coupled receptor in the plasma membrane as revealed by single-molecule techniques. Biophys. J. 88:3659-3680.

83. Svitkina, T.M. and G.G.Borisy. 1999. Arp2/3 complex and actin depolymerizing factor/cofilin in dendritic organization and treadmilling of actin filament array in lamellipodia. J. Cell Biol. 145:1009-1026.

84. Tajima, N., K.Schonherr, S.Niedling, M.Kaatz, H.Kanno, R.Schonherr, and S.H.Heinemann. 2006. $\mathrm{Ca}^{2+}$-activated $\mathrm{K}^{+}$channels in human melanoma cells are up-regulated by hypoxia involving hypoxia-inducible factor-1alpha and the von Hippel-Lindau protein. J. Physiol 571:349-359.

85. Taylor, R.B., W.P.Duffus, M.C.Raff, and S.de Petris. 1971. Redistribution and pinocytosis of lymphocyte surface immunoglobulin molecules induced by antiimmunoglobulin antibody. Nature New Biol 233:225-229.

86. van Haastert, P.J. and P.N.Devreotes. 2004. Chemotaxis: signalling the way forward. Nat. Rev. Mol. Cell Biol. 5:626-634.

87. Verkman, A.S. 2003. Diffusion in cells measured by fluorescence recovery after photobleaching. Methods Enzymol. 360:635-648. 
88. Vicente-Manzanares, M., D.J.Webb, and A.R.Horwitz. 2005. Cell migration at a glance. J. Cell Sci. 118:4917-4919.

89. Voura, E.B., J.K.Jaiswal, H.Mattoussi, and S.M.Simon. 2004. Tracking metastatic tumor cell extravasation with quantum dot nanocrystals and fluorescence emission-scanning microscopy. Nat. Med. 10:993-998. 
6 Appendix

\subsection{Abbreviations}

AE2

Arp2/3

${ }^{\circ} \mathrm{C}$

Cdc42

EDTA

FBS

FCS

FRAP

HA

HEPES

$\mathrm{hK}_{\mathrm{Ca}} 3.1$

h

k

I

$\lg G$

GFP

GTP

$\mathrm{K}_{\mathrm{Ca}} 3.1$

$\mu$

$\mu \mathrm{m}$

$\mathrm{m}$

M

MEM

MDCK-F cell

$\mathrm{mg}$

$\min$

$\mathrm{ml}$
$\mathrm{Cl}^{-} / \mathrm{HCO}_{3}$ exchanger

Actin-related proteins complex

Degree celsius

Cell division cycle 42 protein

Ethylenediamine tetraacetic acid

Fetal bovine serum

Fluorescence correlation spectroscopy

Fluorescence recovery after photobleaching

Hemagglutinin

4-(2-hydroxyethyl)-1-piperazineethanesulfonic acid

Human isoform of calcium-activated potassium channel 3.1

Hour

Kilo

Liter

Immunoglobulin isotype G

Green fluorescence proteins

Guanosine triphosphate

Calcium-activated potassium channel 3.1 (Intermediate-conductance)

Micro

Micro meter

Milli

Molar

Minimum essential medium

Alkaline stress transforms Madin-Darby canine kidney cell

Milli gram

Minute

Milli liter 
$\mathrm{mM}$

$\mathrm{ms}$

$\mathrm{nm}$

NHE1

PBS

PDF

pix

Rac

RhoA

$\mathrm{S}$

SPT

QD

QD565

QD655

TIRF
Milli molar

Milli second

Nano meter

$\mathrm{Na}^{+} / \mathrm{H}^{+}$exchanger

Phosphate-buffered saline

Probability distribution function

Pixel

Small GTP-binding protein

Ras homology gene family, member A protein Second

Single particle tracking

Quantum dot

Quantum dot that emits at $565 \mathrm{~nm}$

Quantum dot that emits at $655 \mathrm{~nm}$

Total internal reflection fluorescence 


\subsection{Acknowledgements}

I want to deeply thank my present chiefs Professor Dr. Hans Oberleithner and Professor Dr. Albrecht Schwab for their patience, excellent scientific guidance, good human and working example. Without their care and consideration, this thesis would likely not have matured.

It is my pleasure to thank my current supervisor Professor Dr. Otto Greulich for providing me an opportunity to defend my thesis in Frindrich-Schiller-University Jena. The supervision of Professor Greulich as well as his practical advice concerning the arrangements of the dissertation were highly valuable.

I would like to thank Professor Dr. Stefan Heinemann for kind agreement to be my second supervisor.

A very special thanks goes out to my scientific collaborator Dr. Peter Dieterich for performing high quality calculations and simulations as well as explanation of many mathematical aspects of dynamics.

My current colleagues from the Physiology II supported me in my research work. I want to thank them for all their help, support, interest and valuable hints. Especially I am obliged to Armin Kramer, Dr. Christian Stock, Dr. Hermann Schillers, Dr. Anke Fabian, Dr. Christoph Riethmüller. I also want to thank Hannelore Arnold and Sabine Mally for technical support and Hildegard Bräuer for stimulating suggestions and encouragement.

I would like to express since thanks to all the members of the Working group of Single Cell and Single Molecule Technique in Jena for their wonderful friendship and uncompromising kindness when it comes to help with things work-related and beyond. I would like to warmly thank all those people who have contributed to this work with their valuable support and interest, especially, Professor Dr. Eberhard Unger, Dr. Konrad Böhm, Marina Baum, Roland Stracke, Marina Wollmann and all 
those I have not mentioned. I also express my thanks and gratitude to Kornelia Haus for her constant help.

My collaborators from Prague: Dr. Pavel Draber and Dr. Vadim Sulimenko as well substantially contributed to the development of my skills. Especially the best teaching in biochemical methods, strict and extensive comments and the many discussions and the interactions with them had a direct impact on my scientific qualification.

I have met great friends at FLI and Physiology II, particularly Irina, Nelly, Kamran, Maria, Armin. They looked closely at the final version of the thesis for English style and grammar, correcting both and offering suggestions for improvement.

My thanks go out to Frank and Elena Santos giving me suggestions in English grammar. 


\subsection{Selbständigkeitserklärung}

I hereby declare that this thesis was composed by myself and that the work described is my own, unless otherwise stated.

Hiermit versichere ich, die vorliegende Arbeit selbständig und ohne fremde Hilfe verfasst und keine anderen als die angegebenen Quellen und Hilfsmittel verwendet zu haben.

Fernen versichere ich, dass ich diese Dissertation noch an keiner anderen Universität eingereicht habe, um ein Promotionsverfahren eröffnen zu lassen.

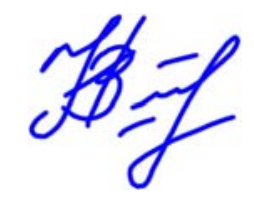

Münster, 23.04.2007

Volodymyr Nechyporuk-Zloy 


\subsection{List of Publications}

Sulimenko, V., T. Sulimenko, S. Poznanovic, V. Nechiporuk-Zloy, K. J. Bohm, L. Macurek, E. Unger, and P. Draber. 2002. Association of brain gamma-tubulins with alpha beta-tubulin dimers. Biochem. J. 365:889-895.

Nechyporuk-Zloy V., C. Stock, H. Schillers, H. Oberleithner, and A. Schwab. 2006. Single plasma membrane $\mathrm{K}^{+}$channel detection by using dual-color quantum dot labeling. Am. J. Physiol Cell Physiol 291:C266-C269.

Schwab, A., A. Wulf, C. Schulz, W. Kessler, V. Nechyporuk-Zloy, M. Romer, J. Reinhardt, D. Weinhold, P. Dieterich, C. Stock, and S. C. Hebert. 2006. Subcellular distribution of calcium-sensitive potassium channels (IK1) in migrating cells. J. Cell Physiol 206:86-94.

Schwab A, V. Nechyporuk-Zloy, A. Fabian and C. Stock. 2007. Cells move when ions and water flow. Pflugers Arch 453: 421-432.

\section{Submitted Papers}

Schwab A., V. Nechyporuk-Zloy, B. Gassner, C. Schulz, W. Kessler, S. Mally. 2007. Dynamic redistribution of calcium sensitive potassium channels (hIK1) in migrating cells.

Kusche, K., K. Sobczak, N. Bangel, V. Nechyporuk-Zloy, M. Wilhelmi, H. Schillers, A. Schwab, H. Oberleithner. 2007. Aldosterone and amiloride modulate ENaC abundance in vascular endothelium. J. Cell Sci.

Nechyporuk-Zloy, V., P. Dieterich, H. Oberleithner, C. Stock, A. Schwab. 2007. Dynamics of single potassium channel proteins in the membrane of migrating cells. 


\subsection{List of Presentations}

2005

Invited Talk: "Single membrane potassium channel detection" CeNTech, Münster, Germany

Workshop Cell Biology and Microscopy: "Identification of single potassium channel proteins in migrating cells by using dual-colour quantum dot labeling" Altleiningen, Germany

2006

$12^{\text {th }}$ International Workshop on Single Molecule Spectroscopy: "Tracking of single potassium channel proteins in migrating cells by quantum dot labeling" PicoQuant, Berlin, Germany

2007

Invited Talk: "Dynamics of single potassium channel proteins in migrating cells " The Institute of General Zoology and Genetics, Münster, Germany

Invited Talk: "Dynamics of single potassium channel proteins in migrating cells " The Biotechnological Centre (BIOTEC) of the Technical University, Dresden, Germany

Invited Talk: "Detection and dynamics of single potassium channel proteins in migrating cells" The Interdisciplinary Nanoscience Center (iNANO) of the University of Aarhus, Denmark

$86^{\text {th }}$ congress of the German Society of Physiology: "Dynamics of single potassium channel proteins the plasma membrane of migrating cells" Hannover, Germany 


\subsection{Supplemental Material}
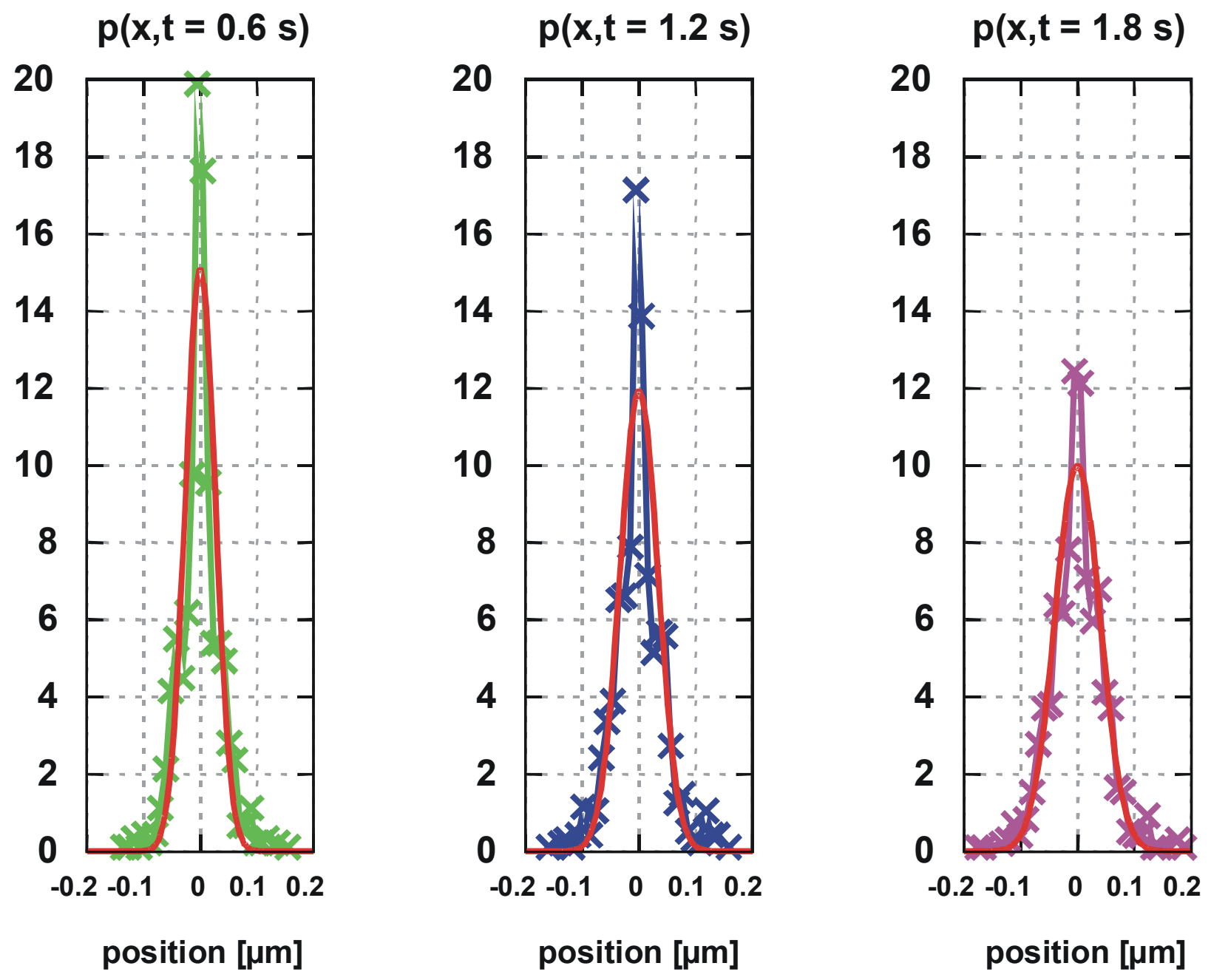

Figure 1: Uncertainty of position measurement. The green, blue, and magenta show the probability distribution function of immobile QDs on the glass for different time interval in $x$ direction. The red curve represents the Gaussian fitting. 

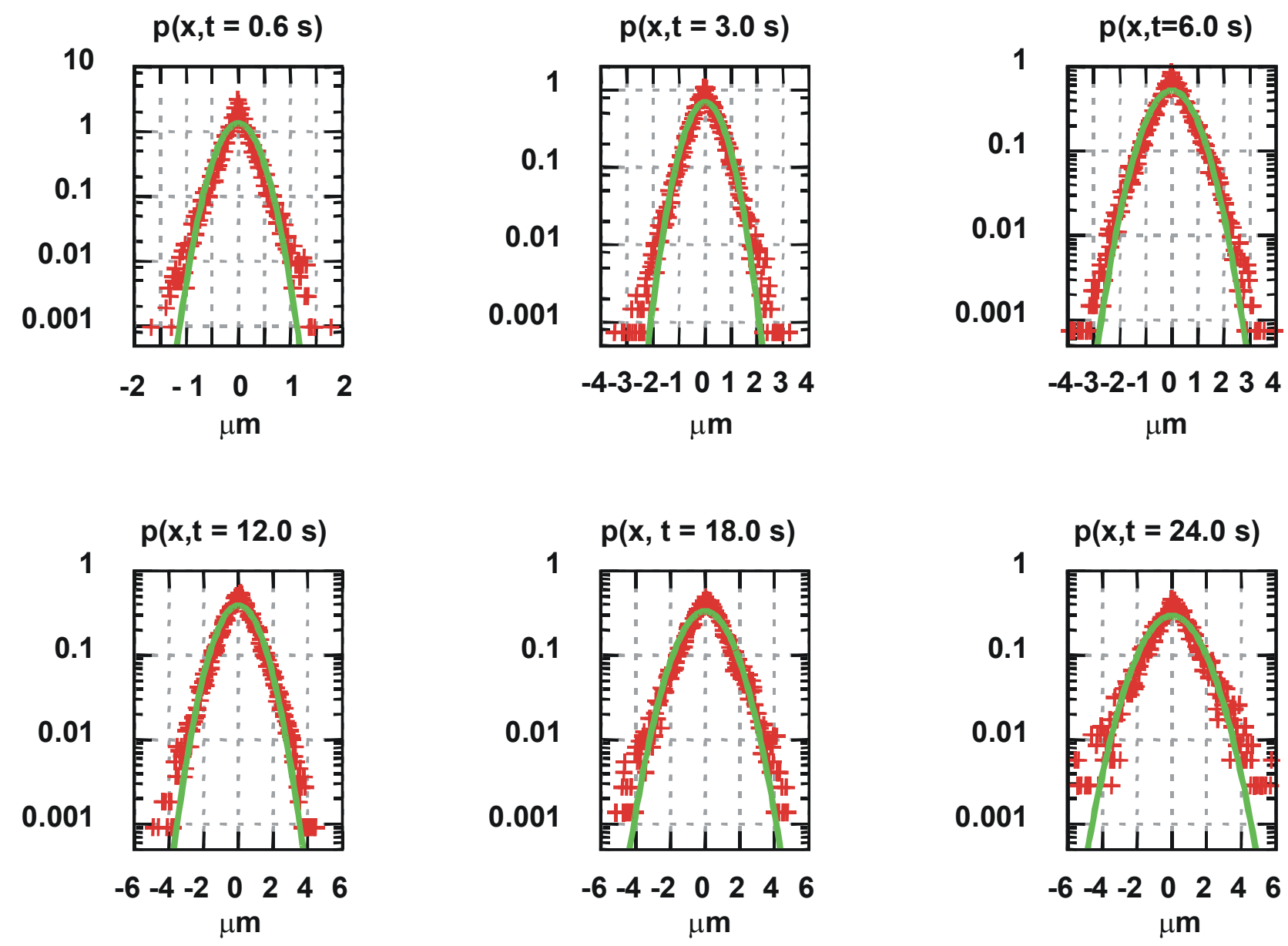

Figure 2: Probability distribution function of the $Q D$ labeled $h K_{\mathrm{Ca}^{3}} 3.1$ channels in the plasma membrane of migrating MDCK-F cells. The red show experimental data. The green line represents the Gaussian fitting, which is representative for free diffusion. 
Table 1. Drift estimation

\begin{tabular}{|c|c|c|c|c|}
\hline cell & $\mathrm{N}$ & $\mathrm{D}_{\alpha}\left[\mu \mathrm{m}^{2} / \mathrm{s}^{\alpha}\right]$ & $\alpha$ & $\mathrm{v}_{\text {drift }}[\mu \mathrm{m} / \mathrm{s}]$ \\
\hline 01 & 79 & $0.0567 \pm 0.0011$ & $0.8852 \pm 0.0147$ & $0.0036 \pm 0.0185$ \\
\hline 02 & 29 & $0.0843 \pm 0.0038$ & $0.7771 \pm 0.0315$ & $0.0011 \pm 0.02327$ \\
\hline 03 & 30 & $0.0653 \pm 0.0030$ & $0.7951 \pm 0.0445$ & $0.0271 \pm 0.0302$ \\
\hline 04 & 60 & $0.0809 \pm 0.0033$ & $0.8013 \pm 0.0336$ & $0.0025 \pm 0.0259$ \\
\hline 05 & 83 & $0.0562 \pm 0.0010$ & $0.7279 \pm 0.0107$ & $0.0019 \pm 0.0086$ \\
\hline 06 & 30 & $0.0748 \pm 0.0038$ & $0.8648 \pm 0.0562$ & $0.0016 \pm 0.0660$ \\
\hline 07 & 74 & $0.0952 \pm 0.0024$ & $0.6929 \pm 0.0148$ & $0.0026 \pm 0.0103$ \\
\hline 08 & 30 & $0.0625 \pm 0.0036$ & $0.8635 \pm 0.0452$ & $0.0137 \pm 0.0215$ \\
\hline 09 & 71 & $0.0576 \pm 0.0019$ & $0.8048 \pm 0.0287$ & $0.0004 \pm 0.0240$ \\
\hline 10 & 40 & $0.0665 \pm 0.0021$ & $0.8016 \pm 0.0186$ & $0.0039 \pm 0.0147$ \\
\hline & & & & \\
\hline
\end{tabular}




\section{Legends to movies}

Movie 1. Time-lapse video microscopy showing migration of MDCK-F cells maintained in Leibowitz Medium L-15 (pH 7.1) with FBS (10\%) at $37^{\circ} \mathrm{C}$. The scale bar represents $15 \mu \mathrm{m}$. The time-lapse covers a period of 10 minutes, with approximately 150 seconds elapsed time per second of movie.

Movie 2. Time-lapse total internal reflection fluorescence microscopy showing the motion of single QD-labeled $\mathrm{hK}_{\mathrm{Ca}} 3.1$ channel proteins in plasma membrane of migrating MDCK-F cells. The scale bar represents $15 \mu \mathrm{m}$. The time-lapse covers a period of 30 seconds, with approximately 4 seconds elapsed time per second of movie.

Movies 3 and 4. Time-lapse total internal reflection fluorescence microscopy of single QD-labeled $\mathrm{hK}_{\mathrm{Ca}} 3.1$ channel proteins in plasma membrane the cell shown in movie 2. The scale bar represents $1 \mu \mathrm{m}$. The time-lapse covers a period of 30 seconds, with approximately 4 seconds of elapsed real time per second of movie. The $\mathrm{hK}_{\mathrm{Ca}} 3.1$ channel depicted in movie 3 (Fig. 3.5A, Fig. 3.5B (trajectory 1) is less mobile than the channel protein in movie 4 (Fig. 3.5A, Fig. 3.5B (trajectory 2). The selected $\mathrm{hK}_{\mathrm{Ca}} 3.1$ channels are marked with a circle. 


\title{
6.7 Original Publication
}

\section{Single plasma membrane $\mathrm{K}^{+}$channel detection by using dual-color quantum dot labeling}

\author{
Volodymyr Nechyporuk-Zloy, Christian Stock, Hermann Schillers, \\ Hans Oberleithner, and Albrecht Schwab \\ Institute of Physiology II, University of Münster, Münster, Germany \\ Submitted 16 December 2005; accepted in final form 2 March 2006
}

Nechyporuk-Zloy, Volodymyr, Christian Stock, Hermann Schillers, Hans Oberleithner, and Albrecht Schwab. Single plasma membrane $\mathrm{K}^{+}$channel detection by using dual-color quantum dot labeling. Am J Physiol Cell Physiol 291: C266-C269, 2006. First published March 22, 2006; doi:10.1152/ajpcell.00633.2005.- $\mathrm{K}^{+}$ channels are widely expressed in eukaryotic and prokaryotic cells, where one of their key functions is to set the membrane potential. Many $\mathrm{K}^{+}$channels are tetramers that share common architectural properties. The crystal structure of bacterial and mammalian $\mathrm{K}^{+}$ channels has been resolved and provides the basis for modeling their three-dimensional structure in different functional states. This wealth of information on $\mathrm{K}^{+}$channel structure contrasts with the difficulties to visualize single $\mathrm{K}^{+}$channel proteins in their physiological environment. We describe a method to identify single $\mathrm{Ca}^{2+}$-activated $\mathrm{K}^{+}$ channel molecules in the plasma membrane of migrating cells. Our method is based on dual-color labeling with quantum dots. We show that $>90 \%$ of the observed quantum dots correspond to single $\mathrm{K}^{+}$ channel proteins. We anticipate that our method can be adopted to label any other ion channel in the plasma membrane on the single molecule level.

$\mathrm{Ca}^{2+}$-activated $\mathrm{K}^{+}$channel; migration

POTASSIUM CHANNELS are expressed ubiquituously in prokaryotic and eukaryotic cells, where one of their key functions is to set the cell membrane potential (9). Most $\mathrm{K}^{+}$channels are tetrameric proteins, and they share a conserved sequence within the "pore loop" (2). Great progress has been made with respect to the resolution of their crystal structure. Both prokaryotic and eukaryotic $\mathrm{K}^{+}$channels have been crystallized so that their structure could be determined with $\AA$ resolution $(4,7,13,15$, 16). However, the vast heterogeneity of $\mathrm{K}^{+}$channels still poses difficult questions. $\mathrm{K}^{+}$channels not only form the largest family of ion channels. Depending on which genome is studied, $30-100 \mathrm{~K}^{+}$channel genes are known. The diversity of $\mathrm{K}^{+}$ channels is further increased by the fact that they frequently form heteromers composed of subunits from different $\mathrm{K}^{+}$ channel family members (18). Thus it remains a great challenge to determine the exact molecular $\mathrm{K}^{+}$channel composition of a given cell. These difficulties are in part due to the lack of easily accessible tools for single molecule detection.

In our view, quantum dots (QDs; 1, 17) allow the identification of $\mathrm{K}^{+}$channel proteins on the single molecule level by means of fluorescence microscopy. QDs were introduced as inorganic dyes, which compared with organic dyes are more bright, stable against photobleaching (5), and have narrow, tunable, and symmetric emission spectra, whose maxima de-

Address for reprint requests and other correspondence: A. Schwab, Institute of Physiology II, Univ, of Münster. Robert-Koch-Strasse 27b, D-48149 Münster, Germany (e-mail: aschwab@uni-muenster.de). pend on the size of QDs (3). QDs used in our study are composed of a core of cadmium selenide that is surrounded by a shell of zinc sulfide. Water solubility and attachment of QDs to biological molecules such as antibodies, lectins, or nucleic acids is mediated by a coating with organic molecules covalently attached to the surface of the shell. QDs are versatile dyes that are used in applications that range from labeling tumor cells within an organism (24) to studying the signaling cascade of epidermal growth factor in living Chinese hamster ovary cells (14). We used a transformed renal epithelial MadinDarby canine kidney cell line (MDCK-F), which serves as a model for studying the function and distribution of ion channels in migrating cells (21). The morphology of MDCK-F cells is ideal for resolving the distribution of $\mathrm{Ca}^{2+}$-activated $\mathrm{K}^{+}$ channels $(10,12 ;$ hIK 1$)$ at a single molecule level. They extend a large and flat lamellipodium into the direction of movement. It provides an almost two-dimensional surface for the detection of single hIK1 channel molecules within the plasma membrane.

\section{METHODS}

Materials. All reagents were of analytical grade. We used fetal bovine serum (FBS) from Biochrom (Berlin, Germany). QD565 and QD655 conjugates with goat $\mathrm{F}\left(\mathrm{ab}^{\prime}\right)_{2}$ anti-mouse IgG were from Quantum Dot (Hayward, CA). Primary antibodies against hemagglutinin (HA) were from Roche Diagnostics (Mannheim, Germany).

Channel construct and transfected cell line. MDCK-F cells (19) were transfected as described previously with a modified hIK1 channel containing an HA tag in the extracellularly located S3-S4 linker (22) and maintained in $\mathrm{CO}_{2} / \mathrm{HCO}_{3}^{-}$-buffered minimal essential medium ( $\mathrm{pH} 7.4$ ) supplemented with $10 \%$ FBS and $600 \mu \mathrm{g} / \mathrm{ml}$ geneticin at $37^{\circ} \mathrm{C}$. Cells were seeded on poly-L-lysine-coated glass coverslips for the experiments.

$Q D$ labeling. We fixed MDCK-F cells with $0.5 \%$ glutaraldehyde in HEPES-buffered Ringer solution ( $\mathrm{pH} \mathrm{7.4)} \mathrm{for} 45$ min directly in the incubator to preserve the intact architecture of the lamellipodium and the ruffled membrane at its leading edge. After fixation, the cells were washed five times in PBS ( $\mathrm{pH} \mathrm{7.4)}$ ) at room temperature, and kept for $30 \mathrm{~min}$ in $100 \mathrm{mmol} / \mathrm{l}$ glycine/PBS solution. After being washed, the cells were blocked with FBS (10\% in PBS) for $1 \mathrm{~h}$ at room temperature, and incubated with primary antibodies against the extracellular HA tag of hIK1 channels (1:600) for $1 \mathrm{~h}$ at room temperature. Antibody specificity was confirmed previously by Western blot analysis (22). The cells were then washed five times in PBS. For one-color labeling, we incubated the cells with goat $\mathrm{F}\left(\mathrm{ab}^{\prime}\right)_{2}$ anti-mouse IgG conjugated with QDs (1:50) for $1 \mathrm{~h}$ at room temperature, and for multicolor labeling with a mixture of QD565 and QD655 goat F(ab' $)_{2}$ anti-mouse IgG conjugates (1:25 and 1:100, respectively), for $1 \mathrm{~h}$ at

The costs of publication of this article were defrayed in part by the payment of page charges. The article must therefore be hereby marked "advertisement" in accordance with 18 U.S.C. Section 1734 solely to indicate this fact. 
room temperature. Titers of secondary antibodies were chosen such that QD565 and QD655 labeled the cells at a similar density. Moreover, care was taken that the total density of QDs was low enough to clearly identify them individually. The cells were again washed five times in PBS and fixed by $0.5 \%$ glutaraldehyde in HEPES buffer $(\mathrm{pH}$ 7.4) for $45 \mathrm{~min}$.

Microscopy and data acquisition. Immunofluorescence microscopy was performed with an inverted microscope (Axiovert 200, Zeiss, Oberkochen, Germany) equipped with a digital camera (Visitron, Puchheim, Germany) and a $100 \times 1.45$ oil-immersion objective. Data acquisition and analysis were performed with Metavue software (Visitron). We used the following filters: QD565, $420 \mathrm{~nm}$ excitation, $565 \mathrm{~nm}$ emission (XF302-1 filter; Omega Optical, Brattleboro, VT); QD655, $420 \mathrm{~nm}$ excitation, $655 \mathrm{~nm}$ emission (XF305-1 filter; Omega Optical). The number of QDs per cell was corrected for background level of QDs determined in cell-free areas. In case of double color labeling, only those cells which had the same number of green and red QDs were taken for further analysis. The pixel with the highest fluorescence intensity was taken as the optical center of a QD. Distance between QDs was then measured as the distance of their optical centers. Pixel shift due to filter change was determined by acquisition of two images of QD-labeled cells in one channel with a filter change (for example, red-green-red) in between. The two images were assigned to different colors, superimposed, and the distances of the optical centers were determined. The mean pixel shift amounted to $0.46 \pm 0.05$ pix $(n=100$ QD pairs).

Statistics. Data are presented as means \pm SE. $N$ refers to the number of MDCK-F cells (see Fig. 3)

\section{RESULTS AND DISCUSSION}

When the distribution of the hIK1 channel in the plasma membrane of MDCK-F cells is visualized with the use of QD labeling (see Fig. 1), the overall staining is similar to previous results obtained with conventional fluorescence labeling (22). The $\mathrm{K}^{+}$channels are more concentrated at the leading edge of the cell than in the remaining membrane of the lamellipodium. The average density of QDs amounts to $\sim 2 \mathrm{QDs} / \mu \mathrm{m}^{2}$, which is similar to the channel density calculated from earlier patchclamp studies. To verify that a single QD corresponds to a single channel and not to a group of single channels, we applied dual-color labeling. We added a mixture of secondary antibodies conjugated either with "red" QDs that emit at 655 $\mathrm{nm}$ (QD655) or with "green" QDs that emit at $565 \mathrm{~nm}$ (QD565) (Fig. 2, $A$ and $B$ ). The titers of the secondary antibodies were adjusted in such a way that they bind with the same efficacy to their target. Consequently, the numbers of

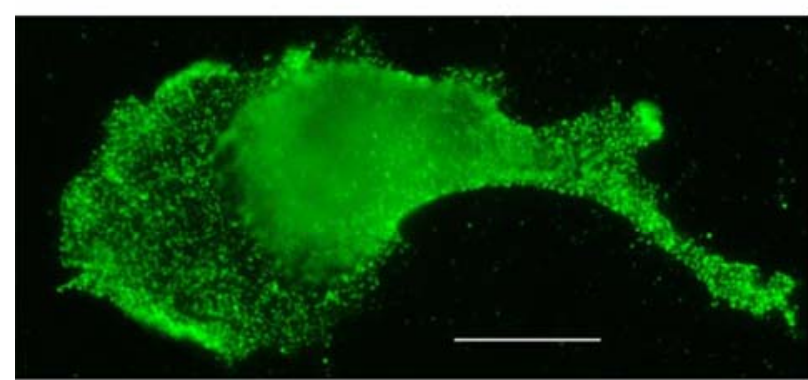

Fig. 1. Detection of $\mathrm{Ca}^{2+}$-activated $\mathrm{K}^{+}$channel molecules (hIK1) channels on the surface of a renal Madin-Darby canine kidney (MDCK-F) cell by quantum dot (QD) labeling. The green spots correspond to hIK1 channel proteins labeled with QD565. The diffuse staining of the cell center is due to glutaraldehyde autofluorescence. Bar: $10 \mu \mathrm{m}$.

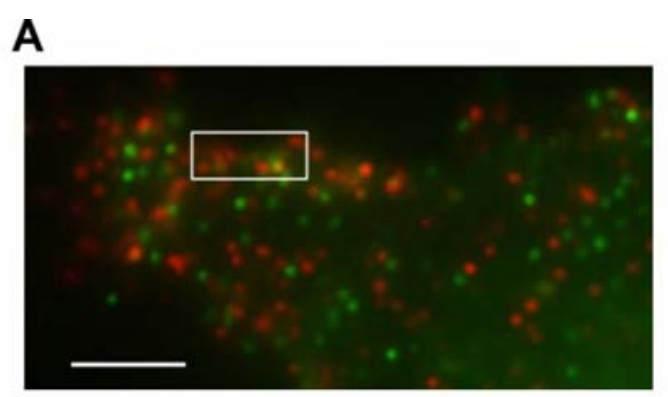

B
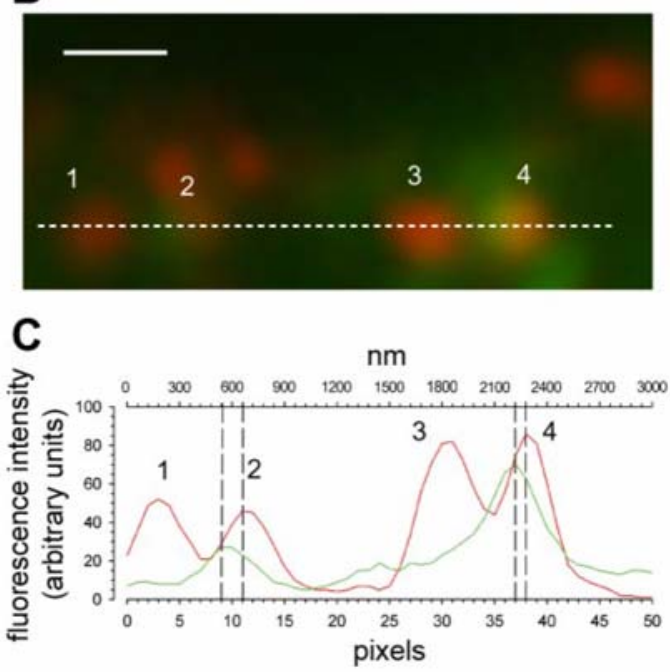

Fig. 2. Multicolor QD labeling of hIKI channel on the surface of a MDCK-F cell. A: leading edge and lamellipodium of the cell. Green and red spots correspond to single hIK1 channel proteins. Yellow spots indicate dual labeling with a pair of QD565 and QD655 with a distance of 1-2 pixels between their optical centers. $B$ : a magnified view of the white rectangle. Bar, $3 \mu \mathrm{m}$. Also shown is the leading edge of the cell. The dashed white line marks four spots, whose intensity profiles are shown in $C$. Spots 1 and 3 are labeled only with red QD655, whereas spots 2 and 4 are dually labeled with green QD565 and red QD655 and therefore appear yellow. Bar, $0.5 \mu \mathrm{m}$. C: intensity profile of fluorescence signal. Vertical dashed lines mark the optical centers of fluorescence signal from single QDs, which are located closely to each other.

QD655 and QD565 per cell are the same (Fig. 3). The merged cell surface image (Fig. 2, $A$ and $B$ ) exhibits many green (QD565) and red (QD655) spots, and only a small fraction of "yellow" spots. Red and green spots could either represent single QDs that mark individual channel proteins or the binding of several red (QD655) or green (QD565) QDs to one channel protein. The appearance of yellow spots in the merged image indicates that red (QD655) and green (QD565) QDs are binding to the $\mathrm{K}^{+}$channel simultaneously. The intensity profile (Fig. 2C) provides a quantitative analysis. Two pairs of red and green QDs are shown. Their optical centers are only 1-2 pixels or $60-120 \mathrm{~nm}$ apart from each other. It is only by the use of the dual-labeling technique that these QDs can be recognized individually. This would not be possible in case of single-color labeling. They would look like one bright single QD. However, most spots are clearly red or green and only a small fraction of spots $(3.3 \%)$ is yellow with different distances between optical centers (Fig. 3). The fraction of yellow spots is hardly affected by doubling the antibody concentrations. 
Each hIK1 channel protein is a tetramer, meaning that it has four binding sites for antibodies and QDs that can be completely or partially occupied. Assuming the equal binding of four QDs to the $\mathrm{K}^{+}$channel the relative frequencies of red and green QDs should behave as predicted by the following binomial distribution: $(a+b)^{4}=a^{4}+4 a^{3} b+6 a^{2} b^{2}+4 a b^{3}+b^{4}$. We derived $a=0.45$ and $b=0.50$ from our experiments (Fig. 3). $a^{4}$ and $b^{4}$ are the probabilities that four green or four red QDs bind to the channel, respectively. $4 a^{3} b+6 a^{2} b^{2}+4 a b^{3}$ is the probability that different combinations of one, two, or three green and red QDs bind simultaneously. We can then calculate that almost $90 \%$ of the channels should be labeled by green and red QDs simultaneously and therefore appear yellow. This is in clear contrast to our experimental findings. We therefore modified our model calculation to the binding of only two QDs per channel protein: $(a+b)^{2}=a^{2}+2 a b+b^{2} \cdot a^{2}$ and $b^{2}$ are the probabilities that two green or two red QDs bind to the channel, and $2 a b$ is the probability that one green and one red QD bind to the channel at the same time (yellow). We can then calculate that $45 \%$ of the channels should be labeled by one green and one red QD and therefore appear yellow which is also in contradiction to our experimental results. We therefore conclude that both models are not valid. In our view, the easiest explanation to account for this apparent discrepancy is to assume that most $\mathrm{K}^{+}$channel molecules are labeled by only one QD.

If channels can be dually labeled by red and green QDs, they can also bind either two (or more) red or two (or more) green QDs, respectively. Our technique does not allow the distinction between binding of one or of multiple QDs of the same color. Thus, we must assume that in addition to $3.3 \%$ dually labeled yellow hIK 1 channels, we also labeled $3.3 \%$ with more than one red or green QD, respectively. Nonetheless, $93.4 \%$ of the QDs observed are single and labeled single $\mathrm{K}^{+}$channel molecules.

$\mathrm{K}^{+}$channel proteins have a diameter of $\sim 10 \mathrm{~nm}(11,23)$. Antibodies have a size of $8 \mathrm{~nm}(8)$, and according to the manufacturer, the diameter of the QDs used in our study is 10 $\mathrm{nm}$. Thus the maximal distance between the optical centers of two QDs bound to a single channel protein is in the order of 50 $\mathrm{nm}$ (Fig. 4). This corresponds to a distance of 1 pixel in the digitized image. Therefore, two QDs with a distance between optical centers of more than two pixels must be placed on two
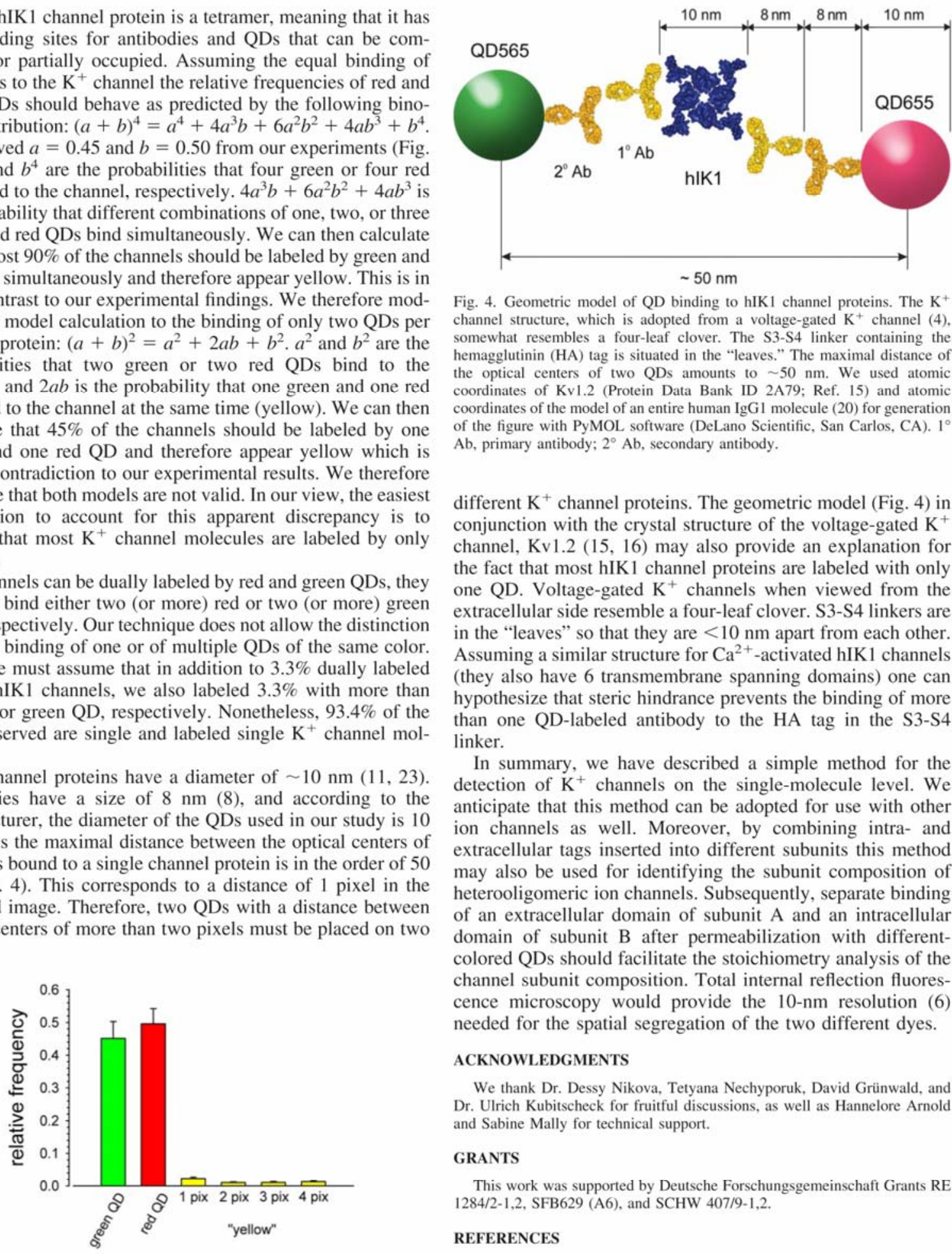

Fig. 4. Geometric model of QD binding to hIK1 channel proteins. The $\mathrm{K}^{+}$ channel structure, which is adopted from a voltage-gated $\mathrm{K}^{+}$channel (4), somewhat resembles a four-leaf clover. The S3-S4 linker containing the hemagglutinin (HA) tag is situated in the "leaves." The maximal distance of the optical centers of two QDs amounts to $\sim 50 \mathrm{~nm}$. We used atomic coordinates of Kv1.2 (Protein Data Bank ID 2A79; Ref. 15) and atomic coordinates of the model of an entire human IgG1 molecule (20) for generation of the figure with PyMOL software (DeLano Scientific, San Carlos, CA). $1^{\circ}$ $\mathrm{Ab}$, primary antibody; $2^{\circ} \mathrm{Ab}$, secondary antibody.

different $\mathrm{K}^{+}$channel proteins. The geometric model (Fig. 4) in conjunction with the crystal structure of the voltage-gated $\mathrm{K}^{+}$ channel, Kv1.2 $(15,16)$ may also provide an explanation for the fact that most hIK1 channel proteins are labeled with only one QD. Voltage-gated $\mathrm{K}^{+}$channels when viewed from the extracellular side resemble a four-leaf clover. S3-S4 linkers are in the "leaves" so that they are $<10 \mathrm{~nm}$ apart from each other. Assuming a similar structure for $\mathrm{Ca}^{2+}$-activated hIK1 channels (they also have 6 transmembrane spanning domains) one can hypothesize that steric hindrance prevents the binding of more than one QD-labeled antibody to the HA tag in the S3-S4 linker.

In summary, we have described a simple method for the detection of $\mathrm{K}^{+}$channels on the single-molecule level. We anticipate that this method can be adopted for use with other ion channels as well. Moreover, by combining intra- and extracellular tags inserted into different subunits this method may also be used for identifying the subunit composition of heterooligomeric ion channels. Subsequently, separate binding of an extracellular domain of subunit A and an intracellular domain of subunit B after permeabilization with differentcolored QDs should facilitate the stoichiometry analysis of the channel subunit composition. Total internal reflection fluorescence microscopy would provide the $10-\mathrm{nm}$ resolution (6) needed for the spatial segregation of the two different dyes.

\section{ACKNOWLEDGMENTS}

We thank Dr. Dessy Nikova, Tetyana Nechyporuk, David Grünwald, and Dr. Ulrich Kubitscheck for fruitful discussions, as well as Hannelore Arnold and Sabine Mally for technical support.

\section{GRANTS}

This work was supported by Deutsche Forschungsgemeinschaft Grants RE 1284/2-1,2, SFB629 (A6), and SCHW 407/9-1,2.

\section{REFERENCES}

Fig. 3. Relative frequency of dual-color QD binding to hIK1 channel proteins. The bars colored yellow give the frequencies of labeling hIK 1 channel proteins with green QD565 and red QD655 simultaneously. The distances of the optical centers of the QDs are indicated. $N=14$ MDCK-F cells.

1. Alivisatos AP. Semiconductor clusters, nanocrystals, and quantum dots. Science 271: 933-937, 1996.

2. Biggin PC, Roosild T, and Choe S. Potassium channel structure: domain by domain. Curr Opin Struct Biol 10: 456-461, 2000. 
3. Bruchez M Jr, Moronne M, Gin P, Weiss S, and Alivisatos AP. Semiconductor nanocrystals as fluorescent biological labels. Science 281 2013-2016, 1998.

4. Capener CE, Kim HJ, Arinaminpathy Y, and Sansom MSP. Ion channels: structural bioinformatics and modelling. Hum Mol Genet 11: 2425-2433, 2002.

5. Chan WC and Nie S. Quantum dot bioconjugates for ultrasensitive nonisotopic detection. Science 281: 2016-2018, 1998.

6. Churchman LS, Okten Z, Rock RS, Dawson JF, and Spudich JA. Single molecule high-resolution colocalization of $\mathrm{Cy} 3$ and $\mathrm{Cy} 5$ attached to macromolecules measures intramolecular distances through time. Proc Natl Acad Sci USA 102: 1419-1423, 2005.

7. Doyle DA, Morais Cabral J, Pfützner RA, Kuo A, Gulbis JM, Cohen SL, Chait BT, and MacKinnon R. The structure of the potassium channel: molecular basis of $\mathrm{K}^{+}$conduction and selectivity. Science 280 : 69-77, 1998.

8. Hartmann WK, Saptharishi N, Yang XY, Mitra G, and Soman G. Characterization and analysis of thermal denaturation of antibodies by size exclusion high-performance liquid chromatography with quadruple detection. Anal Biochem 325: 227-239, 2004.

9. Hille B. Ion Channels of Excitable Membranes (3rd ed.). Sunderland, MA: Sinauer, 2001.

10. Ishii TM, Silvia C, Hirschberg B, Bond CT, and Adelman JP. A human intermediate conductance calcium-activated potassium channel. Proc Natl Acad Sci USA 94: 11651-11656, 1997.

11. Jiang Y, Lee A, Chen J, Cadene M, Chait BT, and Mackinnon R. The open pore conformation of potassium channels. Nature 417: 523-526, 2002.

12. Joiner WJ, Wang LY, Tang MD, and Kaczmarek LK. hSK4, a member of a novel subfamily of calcium-activated potassium channels. Proc Nat Acad Sci USA 94: 11013-11018, 1997.

13. Kuo A, Gulbis JM, Antcliff JF, Rahman T, Lowe ED, Zimmer J, Cuthbertson J, Ashcroft FM, Ezaki T, and Doyle DA. Crystal structure of the potassium channel KirBacl.1 in the closed state. Science 300: 1922-1926, 2003.
14. Lidke DS, Nagy P, Heintzmann R, Arndt-Jovin DJ, Post JN, Grecco HE, Jares-Erijman EA, and Jovin TM. Quantum dot ligands provide new insights into erbB/HER receptor-mediated signal transduction. Nat Biotechnol 22: 198-203, 2004.

15. Long SB, Campbell EB, and Mackinnon R. Crystal structure of a mammalian voltage-dependent Shaker family $\mathrm{K}^{+}$channel. Science 309 : 897-903, 2005.

16. Long SB, Campbell EB, and MacKinnon R. Voltage sensor of Kv1.2: structural basis of electromechanical coupling. Science 309: 903-908, 2005.

17. Michalet X, Pinaud FF, Bentolila LA, Tsay JM, Doose S, Li JJ, Sundaresan G, Wu AM, Gambhir SS, and Weiss S. Quantum dots for live cells, in vivo imaging, and diagnostics. Science 307: 538-544, 2005.

18. Miller C. An overview of the potassium channel family. Genome Biol 00: 0004.1-0004.5, 2000.

19. Oberleithner H, Westphale HJ, and Gassner B. Alkaline stress transforms Madin-Darby canine kidney cells. Pflïgers Arch 419: 418-420, 1991.

20. Padlan EA. Anatomy of the antibody molecule. Mol Immunol 31: 169217, 1994.

21. Schwab A. Function and spatial distribution of ion channels and transporters in cell migration. Am J Physiol Renal Physiol 280: F739-F747, 2001.

22. Schwab A, Wulf A, Schulz C, Kessler W, Nechyporuk-Zloy V, Römer M, Reinhardt J, Weinhold D, Dieterich P, Stock C, and Hebert SC. Subcellular distribution of $\mathrm{Ca}^{2+}$-sensitive $\mathrm{K}^{+}$channels in migrating cells. J Cell Physiol 206: 86-94, 2006.

23. Sokolova O, Kolmakova-Partensky L, and Grigorieff N. Three-dimensional structure of a voltage-gated potassium channel at $2.5 \mathrm{~nm}$ resolution. Structure 9: 215-220, 2001.

24. Voura EB, Jaiswal JK, Mattoussi H, and Simon SM. Tracking metastatic tumor cell extravasation with quantum dot nanocrystals and fluorescence emission-scanning microscopy. Nat Med 10: 993-998, 2004 . 